\title{
New records of red seaweeds to the coast of Ceará State, northeastern Brazil ${ }^{1}$
}

\author{
든 $\underline{\text { Landa Pereira Soares }}^{2,4}$, Pedro Bastos de Macedo Carneiro ${ }^{3}$ and Mutue Toyota Fujii ${ }^{2}$
}

Received: 30.06.2017; accepted: 13.04.2018

\begin{abstract}
New records of red seaweeds to the coast of Ceará State, Northeastern Brazil). A recent floristic survey of Rhodophyta from Ceará State, Brazil $\left(02^{\circ} 46^{\prime} 30^{\prime \prime}-07^{\circ} 52^{\prime} 15^{\prime \prime} \mathrm{S}\right.$ and $\left.37^{\circ} 14^{\prime} 54^{\prime \prime}-41^{\circ} 24^{\prime} 45^{\prime \prime} \mathrm{W}\right)$, revealed the occurrence of 113 species distributed into 14 orders, 28 families and 63 genera. Of these, 18 species belonging to seven orders are new records; some of them poorly described and illustrated in the literature or cited only checklists. Therefore, aiming to expand the taxonomic knowledge about these poorly known species, we present detailed descriptions, illustrations, and comments on related taxa. The occurrence of Ceratodictyon scoparium is confirmed for the South Atlantic coast. The male gametophytes of Dohrniella antillarum var. brasiliensis and tetrasporophytes of Gracilariopsis silvana are illustrated for the first time. Ceramium fujianum is a new addition to northeastern Brazil. Among the new records, Callithamnion corymbosum, Ceramium clarionense, $C$. fujianum and C. scoparium showed a significant expansion of their geographic distribution along the Brazilian coast. Most of the newly recorded species are filamentous, small-sized or tufted algae, highlighting the need for new collections to detect the presence of these components.
\end{abstract}

Keywords: biodiversity, Rhodophyta, seaweeds, taxonomy

RESUMO - (Novos registros de algas marinhas vermelhas na costa do Estado do Ceará, Nordeste do Brasil). Um recente

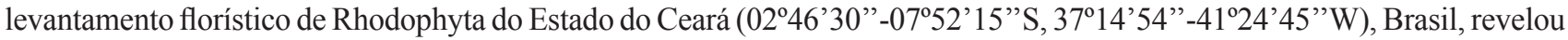
a ocorrência de 113 espécies distribuídas em 14 ordens, 28 famílias e 63 gêneros. Dentre esses, 18 espécies pertencentes a sete ordens são novos registros, algumas pobremente descritas e ilustradas na literatura ou somente citadas em listas. Com o objetivo de expandir o conhecimento taxonômico acerca dessas espécies, são apresentadas descrições detalhadas, ilustrações e comparações com táxons relacionados. A ocorrência de Ceratodictyon scoparium é confirmada na costa do Atlântico Sul. Os gametófitos masculinos de Dohrniella antillarum var. brasiliensis e tetrasporófitos de Gracilariopsis silvana são ilustrados pela primeira vez. Ceramium fujianum é um novo registro para a costa nordeste do Brasil. Dentre as novas ocorrências, Callithamnion corymbosum, Ceramium clarionense, $C$. fujianum and C. scoparium mostraram uma expansão significativa da distribuição geográfica ao longo do litoral brasileiro. A maioria das espécies é filamentosa, diminutas ou formam tufos, demonstrando a necessidade de novas coletas para detectar a presença desses componentes.

Palavras-chave: biodiversidade, macroalgas, Rhodophyta, taxonomia

\section{Introduction}

The extensive coastline of Brazil, which stretches approximately $8500 \mathrm{~km}$, places the country as the holder of one the greatest biological diversities on the planet (Miloslavich et al. 2011, Forzza et al. 2012). However, current anthropogenic impacts are seriously threatening this biota (Cardinale et al. 2012), calling for serious efforts to ensure its conservation. According to Manoylov (2014) and Forest et al. (2015), accurate inventories of species in a given location are the starting point for effective conservation of biodiversity throughout taxonomic surveys.

In biogeographical and ecological terms, the coast of Ceará is located in the extreme northern part of the tropical southwestern Atlantic on the northeast coast of Brazil (Spalding et al. 2007). The extensive sandy beaches are occasionally interrupted by sandstone reefs or beach rocks arranged parallel to the coastline (Ferreira Jr. et al. 2011). This northeastern region is

1. Parte da Tese de Doutorado da primeira Autora

2. Instituto de Botânica, Núcleo de Pesquisa em Ficologia, Av. Miguel Stefano 3687, 04301-902 São Paulo, SP, Brasil

3. Universidade Federal do Ceará, Instituto de Ciências do Mar (Labomar), Av. Abolição 3207, 60165-081 Fortaleza, CE, Brasil

4. Corresponding author: luanda87@gmail.com 
unique by the occurrence of oligotrophic waters and abundance of substrata, enabling the development of rich marine flora (Horta et al. 2001). The coastline is under the influence of highly energetic waves, subhumid climate, high temperatures throughout the year $\left(\sim 26^{\circ} \mathrm{C}\right)$, strong winds and an intense flux of resuspended sediments, despite the lack of fluvial inputs (Testa \& Bosence 1998, Knoppers et al. 1999, Vital et al. 2008, Vital et al. 2010).

In recent decades, the littoral of Ceará has been subjected to intense anthropogenic disturbances, such as increasing urbanization, construction of shrimp farms in estuarine areas, overexploitation of marine resources and inappropriate disposal of domestic sewage. Recent data obtained by Portugal et al. (2016) show that urbanization, in particular jetties built to control coastal erosion, beachfront kiosks and restaurants, fish markets and storm sewers with illegal sewage connections, is significantly threatening benthic biodiversity.

In spite of its importance and the ongoing threats that endanger its biota, the biodiversity along the coast of Ceará remains relatively unknown when compared to other States in Brazil. Specific studies of seaweeds along the coastline of this region were mainly carried out between the 1960s and 1980s (Ferreira \& Pinheiro 1966, Pinheiro-Vieira \& Ferreira 1968, Ferreira-Correia 1969, Ferreira-Correia \& PinheiroVieira 1969, Pinheiro-Vieira \& Ferreira-Correia 1970, Pinheiro-Joventino \& Lima-Verde 1988). The most recent data regarding the flora of this region are limited to the results provided by Pinheiro-Joventino et al. (1998). All these previous publications are mainly lists of species and some new taxa descriptions or new reports on subtidal flora. More recently, Soares (2015) carried out a floristic survey of Rhodophyta from Ceará for the first time based on morphological and molecular evidences, identifying a total of 113 taxa distributed among 14 orders, 28 families and 63 genera.

In this paper, we report 18 new records of red seaweeds for the intertidal zone and provide descriptions, diagnostic characters, illustrations, as well as comparisons between related taxa. The additions presented here will expand taxonomic knowledge of these species in Brazil and Atlantic Ocean.

\section{Materials and methods}

Collections were performed from August 2011 to June 2014 at several sites along the Ceará coast ( $02^{\circ} 46^{\prime} 30^{\prime \prime}-07^{\circ} 52$ ' $15^{\prime \prime} \mathrm{S}$ and $37^{\circ} 14$ ' $54^{\prime \prime}$ $41^{\circ} 24^{\prime} 45^{\prime \prime} \mathrm{W}$ ), northeastern Brazil (figure 1), during low tides in the intertidal zone. Specimens were collected and preserved in $4 \%$ formalin/seawater solution for morphological studies.

Cross sections were made by hand with a stainless steel razor blade and stained with $0.5 \%$ aqueous aniline blue solution acidified in $\mathrm{HCl} 1 \mathrm{~N}$. Permanent slides were prepared and mounted in a $50 \%$ Karo $^{\circledR}$ corn syrup/formalin solution. Photographs were taken using a Panasonic ${ }^{\circledR}$ Lumix DMC-FH4 digital camera coupled to a Stemi 2000-C Zeiss stereomicroscope and Primo Star Zeiss optical microscope. Images were edited with Photoshop CS3 (Adobe Systems). The taxonomic classification follows Wynne (2017), and the taxa are described in alphabetic order.

The voucher specimens are deposited in the Herbarium "Maria Eneyda P. Kauffman Fidalgo" of the Institute of Botany (SP), São Paulo, Brazil.

\section{Results}

Eighteen species of Rhodophyta were newly recorded, comprising seven orders: Ceramiales (nine), Colaconematales (one), Gelidiales (one), Gigartinales (one), Gracilariales (two), Halymeniales (two) and Rhodymeniales (two).

\section{Ceramiales}

\section{Callithamniaceae}

Callithamnion corymbosum (Smith) Lyngbye, Tent. hydrophytol. danicae: $125.1819 \equiv$ Conferva corymbosa Smith, English Bot. 33:2352. 1812. Type locality: England, Brighthelmston.

Figures 2a-e

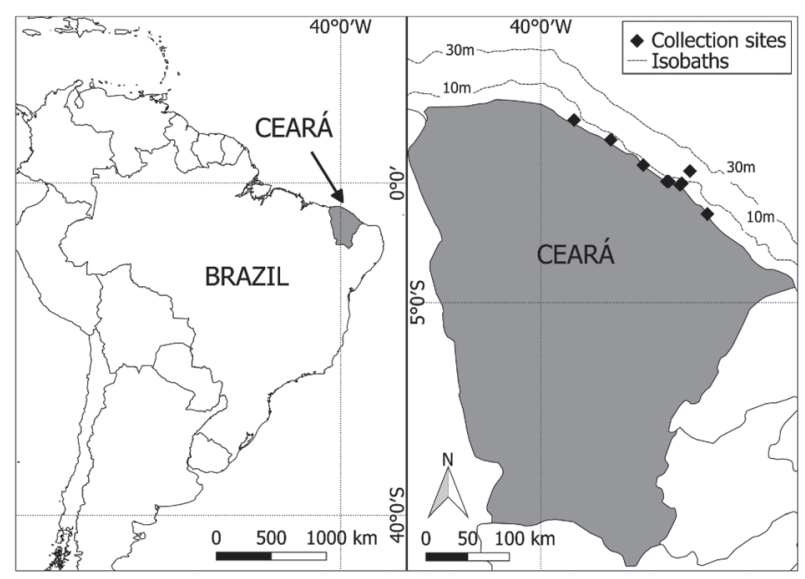

Figure 1. Map of Brazil showing study sites along the Ceará State coast. 
Plants erect, filamentous, pinkish red, 5-25 mm high, uniseriate, ecorticated, forming soft, corymbose tufts, attached to the substratum by multicellular rhizoids. Multinucleate cells. Main axes 50-90 $\mu \mathrm{m}$ wide, branching alternate to subdichotomous, sometimes unilateral, producing branches from the upper half of the thallus. Cells from the apical portions, $50-92.5 \times 37.5-42.5 \mu \mathrm{m}$. Filaments with uniform diameter along the thallus. Hyaline hairs common, 90-300 $\mu \mathrm{m}$ long, apical or subapical, sometimes with digitate tips. Reproductive structures were not observed.

Material examined: BRAZIL. CEARÁ: Caucaia, Pacheco Beach, 341'13.49”S, 38³7'52.54”W, 28-VI-2013, L.P. Soares (SP429198); Fortaleza, Marine State Park Pedra da Risca do Meio, $3^{\circ} 34.39^{\prime}$ S, 38²2.84'W, 13-IV-2013, P.B. Carneiro (SP429247).

Remarks: we confirmed a morphological similarity between specimens collected in Ceará and previous descriptions and illustrations of C. corymbosum from Brazil and other sites in the Atlantic Ocean, except for diameter of the axes (Taylor 1960, Ugadim 1976, Sanson \& Gil-Rodriguez 1993, Mateo-Cid et al. 2003, Nunes et al. 2008, Secilla 2012). These authors described plants up to $6 \mathrm{~cm}$ high and $220 \mu \mathrm{m}$ wide, while the specimens herein analyzed are delicate (up to $25 \mathrm{~mm}$ high and $90 \mu \mathrm{m}$ wide) and thus similar to those described by Oliveira Filho (1969) to Espírito Santo State and Dixon \& Price (1981) to the British Isles. Three species of Callithamnion Lyngbye occur in Brazil: C. callithamnioides (Joly \& Ugadim) Wynne, C. corymbosum and C. tetragonum (Whitering) Gray. Delicate hyaline hairs and filaments with uniform diameter were characters that proved useful in distinguishing C. corymbosum from other species. This is the second record of the species in northeastern Brazil.

Habitat: epiphytic on Gracilariopsis silvana Gurgel, Fredericq \& Norris in the intertidal zone and epilithic in the subtidal zone.

\section{Ceramiaceae}

Acrothamnion butleriae(Collins) Kylin, Die Gattungen der Rhodophyceen: 375. 1956 Antithamnion butleriae Collins, Proc. Am. Acad. Arts and Sci. 37: 258. 1901. Type locality: Jamaica, Kingstom.

Figures 2f-h

Plants composed of prostrate and erect portions, filamentous, pinkish red, 0.5-2 $\mathrm{mm}$ high, uniseriate, ecorticated, attached to the substratum by multicellular rhizoids originated from prostrate axes. Erect axes bipinnate, unbranched at base and profusely branched in the upper half of the thallus. Cells of main axes up to $87.5 \times 37.5 \mu \mathrm{m}$, producing 1-2 short lateral branches, whorl-like, opposite, at right angle, produced at the distal end of cells of main axes. Gland cells flattened on apical cells of branchlets, up to $10 \times 17.5 \mu \mathrm{m}$, showing refractive content. Reproductive structures were not observed.

Material examined: BRAZIL. CEARÁ: São Gonçalo do Amarante, Taíba Beach, 330'31.01'"S, 38 53'14.35'W, 27-VI-2013, L.P. Soares (SP429194), 16-III-2014, L.P. Soares (SP429204), Caucaia, Pacheco Beach, 3०41'13.49”S, 38³7'52.54”'W, 1-IX-2011, L.P. Soares \& M.T. Fujii (SP429217), Cascavel, Caponga Beach, 4²'23.43”'S, 38¹1'32.62'W, 31-VIII-2011, L.P. Soares, P.B. Carneiro \& M.T. Fujii (SP429232).

Remarks: these specimens are similar to those observed by Taylor (1960, as Antithamnion butleriae), Ugadim et al. (1986), Albornoz \& Ganesan (1994), Athanasiadis (1996), Torres et al. (2004) and Nunes et al. (2008). Kylin (1956) transferred Antithamnion Nägeli to Acrothamnion J. Agardh based on habit, disposition of branches and position of gland cells. Reproductive structures are still unknown in the species. The number of whorl-like lateral branches is used to separate $A$. butleriae from $A$. preissi (Sonder) Wollaston, and from the other species of the genus. Acrothamnion preissi produces 3 to 4 lateral branches, while $A$. butleriae exhibits 1 to 2 whorl-like branches. In Brazil, this species occurs only in the tropical region.

Habitat: epiphytic on Gracilaria cuneata Areschoug and Gracilariopsis tenuifrons (Bird \& Oliveira) Fredericq \& Hommersand in the intertidal zone.

Ceramium clarionense Setchell \& Gardner, Proc. Calif.Acad. Sci. 4: 170. 1930. Type locality: Mexico, Clarion Island.

Figures 2i-1

Plants filamentous, dark red, up to $1 \mathrm{~cm}$ high, predominantly erect, attached to the substratum by multicellular rhizoids originated from prostrate axes. Branching pseudodichotomous at intervals of 7-16 segments. Apices strongly forcipate. Nodes with 4-5 cell layers, $50-85 \times 125-200 \mu \mathrm{m}$. Internodes $80-120 \times 115-180 \mu \mathrm{m}$. Rounded to slightly ovated periaxial cells, each one giving rise to two acropetal 

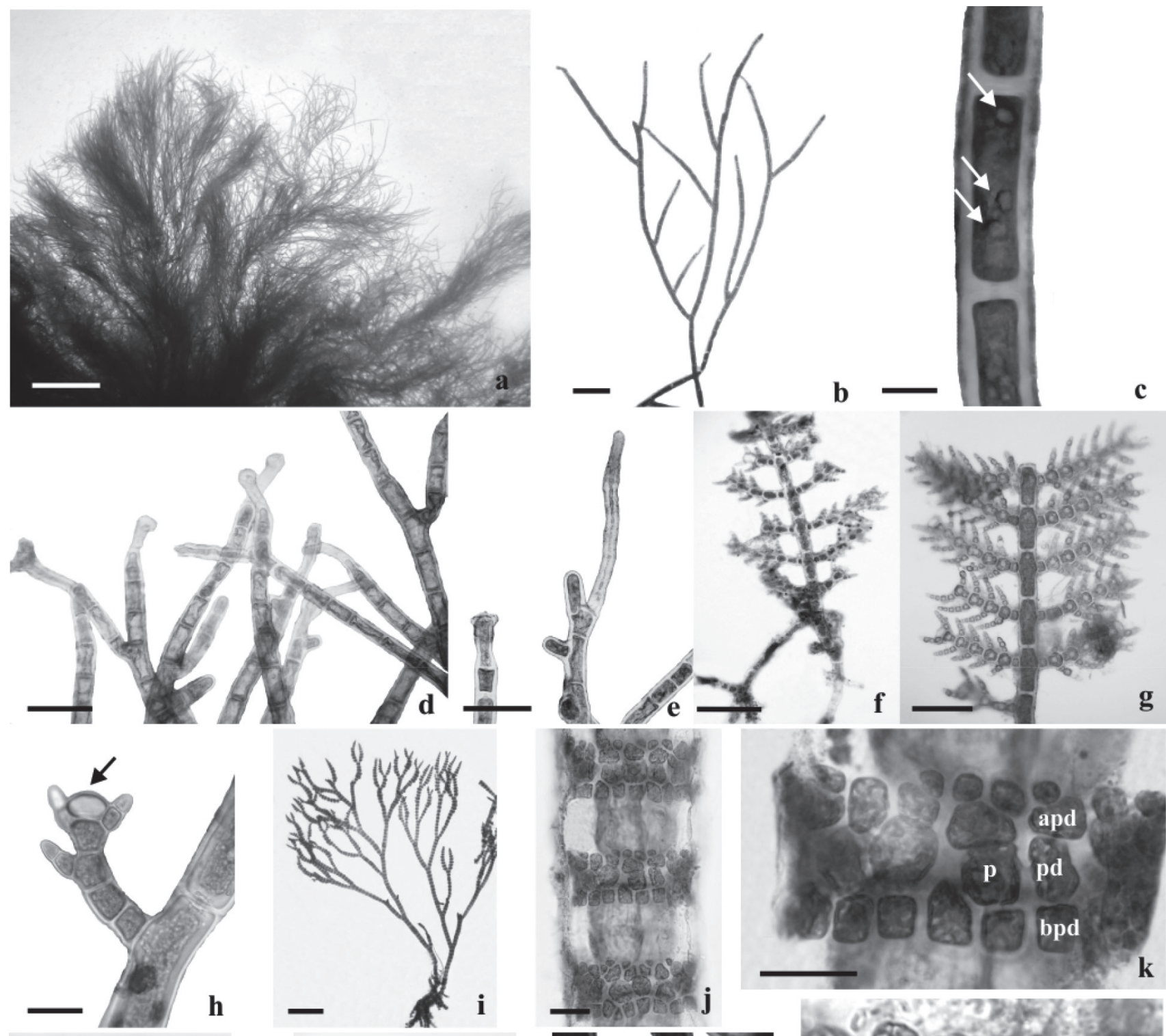

g
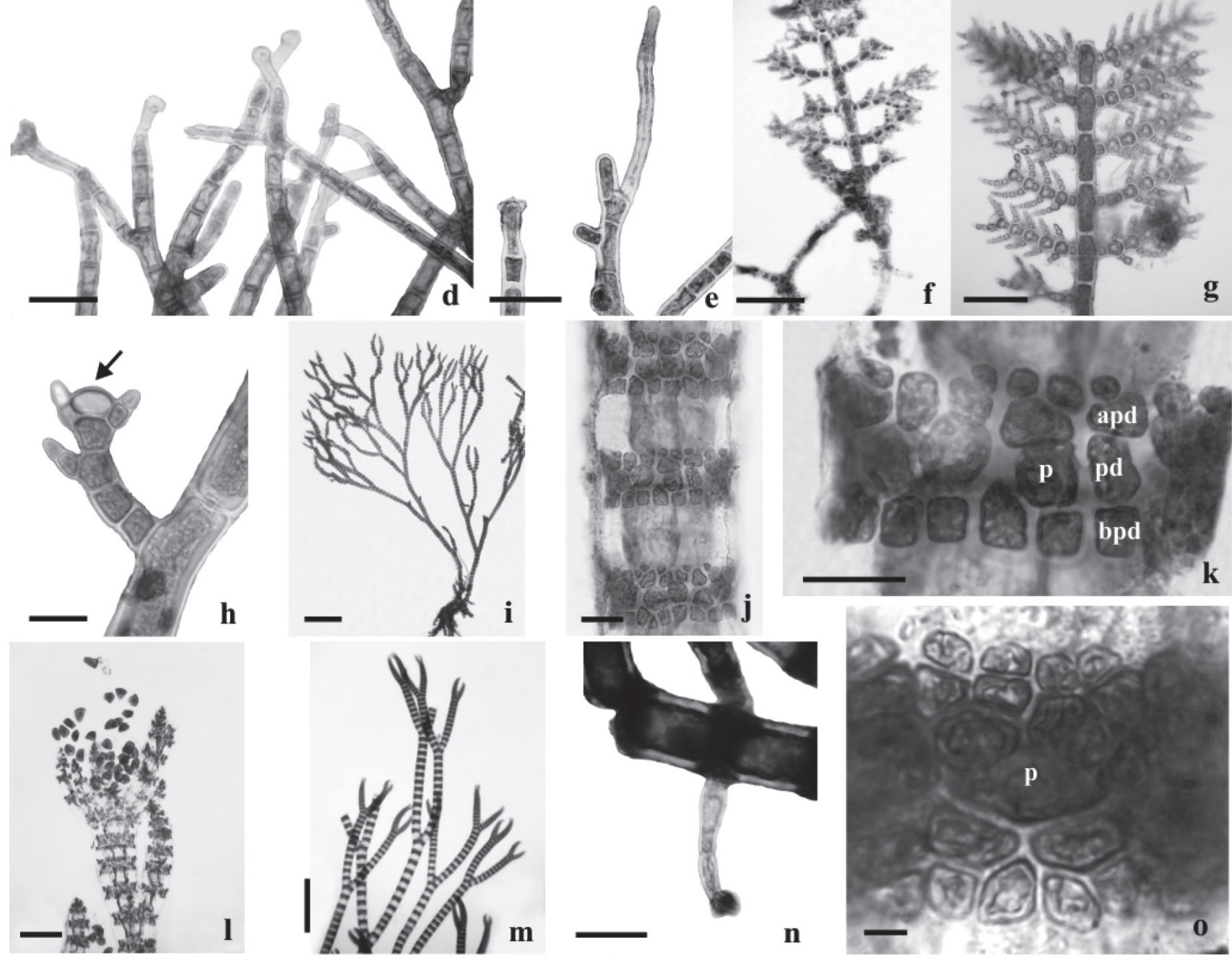

Figure 2. a-e. Callithamnion corymbosum. a. General habit. b. Detail of branching pattern. c. A multinucleate cell (arrows indicate nuclei). d. Apical hyaline hairs. e. Detail of hyaline hairs. f-h. Acrothamnion butleriae. f. General habit. g. Detail of erect axe. h. Detail of gland cell (arrow). i-l. Ceramium clarionense. i. General habit. j. Nodal cortication. k. Detail of the nodal cortication (p: periaxial cell, pd: pseudoperiaxial cell, apd: pseudoacropetal cell, bpd: pseudobasipetal cell). 1. Cystocarp with gonimolobes surrounded by involucral branches. m-o. Ceramium deslongchampsii. m. General habit. $n$. Detail of a smooth multicellular rhizoid. o. Detail of the nodal cortication (p: periaxial cell). Scale bars $=1.5 \mathrm{~mm}$ (a), $250 \mu \mathrm{m}$ (b, m), $25 \mu \mathrm{m}$ (c, h, j, k), $100 \mu \mathrm{m}$ (d-g, 1, n, o), $1 \mathrm{~mm}$ (i). 
cells, two basipetal cells and one pseudoperiaxial cell. Each acropetal cell divides and gives rise to two acropetal daughter cells. In turn, basipetal cells also divide into two basipetal daughter cells. The pseudoperiaxial cells give rise to pseudoacropetal and pseudobasipetal cells. Cystocarps lobed, on the axils of ultimate dichotomies, surrounded by involucral branches. Tetrasporophytes and male gametophyte were not observed.

Material examined: BRAZIL. CEARÁ: Amontada, Icaraí de Amontada Beach, 31'6.37'S, 39³8'20.50'W, 17-III-2014, L.P. Soares (SP468761).

Remarks: the species was originally proposed by Setchell \& Gardner (1930) in a taxonomic survey of seaweeds from Revillagigedo Archipelago in the Mexican Pacific. The first occurrence of $C$. clarionense in Brazil was reported by Barros-Barreto et al. (2007) from the specimens collected at Espírito Santo, Rio de Janeiro and São Paulo. The morphological characteristics analyzed in our material, such as thallus dimensions, apex shape and cortical development, are consistent with those described for specimens from Mexico (type locality, Setchell \& Gardner 1930, Dawson 1962), Brazil (Barros-Barreto et al. 2006, 2007) and Venezuela (García \& Gómez 2009). On the Brazilian coast, Ceramium brevizonatum Petersen var. caraibicum Peterson \& Børgesen and C. tenerrimum (Martens) Okamura are the only species that produce pseudoperiaxial cells. However, these species do not exhibit basipetal cells, and their pseudoperiaxial cells do not divide, while in C. clarionense, the pseudoperiaxial cells give rise to pseudoacropetal and pseudobasipetal cells.

Habitat: epiphytic on Calliblepharis occidentalis Joly $\&$ Yamaguishi-Tomita at the intertidal zone.

Ceramium deslongchampsii Chauvin ex Duby, Bot. Gallicum 2: 967. 1830. Type locality: France, Normandy.

Figures 2m-o

Plants filamentous, pinkish red, up to $1 \mathrm{~cm}$ high, predominantly erect, attached to the substratum by multicellular rhizoids with simple tips, originated from prostrate axes. Erect axes with 112.5-120 $\mu \mathrm{m}$ wide. Pseudodichotomous branching at intervals of 12-18 segments. Recurved, tapered, pincer-like apices. Nodes with 6-7 cell layers. Large, rhomb-like periaxial cells, up to $17 \times 30 \mu \mathrm{m}$, giving rise to two acropetal cells and two basipetal cells. Each acropetal cell divides and produces two acropetal daughter cells, which can divide again. Each basipetal cell gives rise to two basipetal daughter cells. Reproductive structures were not observed.

Materia examined: BRAZIL. CEARÁ: Caucaia, Pacheco Beach, 341'13.49”'S, 38³7'52.54”W, 28-VI-2013, L.P. Soares (SP468767).

Remarks: the specimens described in this study are consistent with those reported to Brazil (Barreto \& Yoneshigue-Valentin 2001, Torres et al. 2004, Nunes et al. 2008), Florida (Dawes \& Mathieson 2008) and Spain (Secilla 2012). Slender and delicate axes, tapered apices and rhomb-like periaxial cells were the main features used to identify the specimens.

Habitat: collected in upper intertidal zone in association with Centroceras gasparrinii (Meneghini) Kützing.

Ceramium fujianum Barros-Barreto \& Maggs, J. Phycol. 42: 915. 2006. Type locality: Brazil, Espírito Santo.

Figures 3a-f

Plants filamentous, intense red, up to $12 \mathrm{~mm}$ high, predominantly erect, attached to the substratum by multicellular rhizoids with simple tips. Erect axes with 62.5-70 $\mu \mathrm{m}$ wide. Branching pseudodichotomous at intervals of 10-14 segments. Straight to slightly recurved apices. Long axial cells, 175-225 $\mu \mathrm{m}$ high, in the middle portions. Nodes with 6-7 rows of cells. Rhomb-like periaxial cells, giving rise to two acropetal and basipetal cells. Each acropetal cell divides and produces two acropetal daughter cells, which can divide again. Each basipetal cell gives rise to two basipetal daughter cells. Carposporophyte with 1-2 spherical gonimolobes, surrounded by 4-6 tapered and straight vegetative branchlets. Tetrasporangia tetrahedral, whorled, 3-4 per node, partially covered by cortical cells. Male gametophytes were not observed.

Material examined: BRAZIL. CEARÁ: São Gonçalo do Amarante, Taíba Beach, 3³0’31.01'S, 38 53'14.35”W, 16-III-2014, L.P. Soares (SP429188), Caucaia, Pacheco Beach, 341'13.49”'S, 38³7'52.54”W, 26-VI-2013, L.P. Soares (SP429189).

Remarks: Ceramium fujianum was proposed by Barros-Barreto et al. (2006) from material collected in Enseada das Garças, Espírito Santo State. Later, Moreira \& Fujii (2010) recorded, for the first time, $C$. fujianum outside of Brazil in Cienfuegos Bay, Cuba. The specimens from Ceará are similar to material 


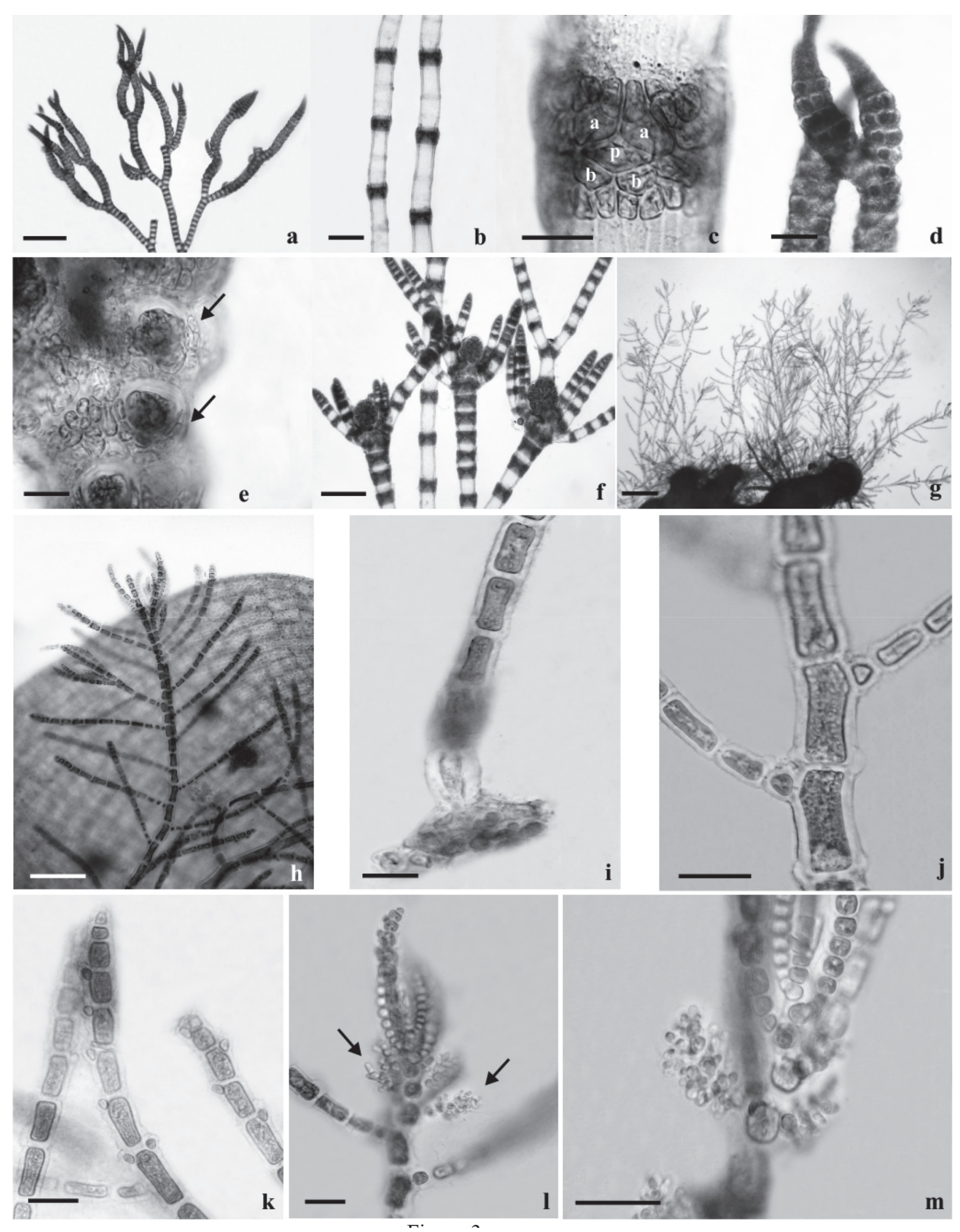

Figure 3. a-f. Ceramium fujianum. a. General habit. b. Detail of nodes and internodes. c. Detail of the nodal cortication (p: periaxial cell, a: acropetal cell, b: basipetal cell). d. Whorled tetrasporangia in stichidia-like structures. e. Detail of tetrasporangia partially covered by cortical cells (arrows). f. Cystocarps with gonimolobes surrounded by involucral branches. g-m. Dohrniella antillarum var. brasiliensis. g. General habit. h. Detail of alternate branching. i. Digitate rhizoid. j. Detail showing the small basal cells of lateral branches. k. Apical branch showing papilliform cells, singly or up to 2 per branch cell. 1. Spermatangial branches (arrows). m. Detail of spermatangial structures. Scale bars $=250 \mu \mathrm{m}(\mathrm{a}, \mathrm{h}), 25 \mu \mathrm{m}(\mathrm{b}, \mathrm{c}, \mathrm{e}, \mathrm{i}-\mathrm{m}), 100 \mu \mathrm{m}(\mathrm{d}, \mathrm{f}), 1.6 \mathrm{~mm}(\mathrm{~g})$. 
analyzed by these authors, except for the length of the axial cells, which were shorter than that of the type material. Ceramium fujianum can be confused with $C$. deslongchampsii with respect to nodal development, branching pattern and shape of apices. In the local flora, C. fujianum differs from C. deslongchampsii by the narrower axes, longer axial cells and shorter branching interval. Tetrasporangia are whorled, stichidia-like in $C$. fujianum and uni- or bilateral in $C$. deslongchampsii. This is the first record of $C$. fujianum for northeastern Brazil.

Habitat: epiphytic on Parviphycus trinitatensis (Taylor) Wynne and associated with Centroceras gasparrinii and Gracilariopsis tenuifrons.

Dohrniella antillarum (Taylor) Feldmann-Mazoyer var. brasiliensis Joly \& Ugadim, Bol. Fac. Fil. Ciênc. Let. Univ. São Paulo, Botânica 20: 13.1963 $\equiv$ Actinothamnion antillarum Taylor, Am. J. Bot. 16: 660. 1929. Type locality: Brazil, São Paulo.

Figures 3g-m

Plants filamentous, reddish pink, uniseriate, ecorticated, up to $3 \mathrm{~mm}$ long, forming delicate tufts on hosts, attached to the substratum by multicellular rhizoids with digitate tips. Erect axes alternately branching, giving rise to short lateral branches, reaching $300 \mu \mathrm{m}$ in length, one per segment, slightly recurved in the apices, with small basal cells up to $12.5 \mu \mathrm{m}$ in diameter. Rounded to ovate papilliform cells produced in the lateral branch apices, 2-5 per branch unilaterally arranged. Eventually, two papilliform cells occur per cell branch. Spermatangial structures borne on ultimate branches, in diminutive filaments, stalked and rounded. Tetrasporophyte and female gametophytes were not observed.

Material examined: BRAZIL. CEARÁ: Amontada, Icaraí de Amontada Beach, 31'6.37'S, 39³8'20.50"W, 17-III-2014, L.P. Soares (SP429227), São Gonçalo do Amarante, Taíba Beach, 3०30'31.01"S, 38 53'14.35”'W, 27-VI-2013, L.P. Soares (SP468783), Caucaia, Dois Coqueiros Beach, 3०41'18.40"S, 38³6’38.61”'W, 25-VI-2013, L.P. Soares (SP429228).

Remarks: the features observed in the specimens examined are consistent with those described by Joly et al. (1963) from type material, Oliveira Filho (1969) from Espírito Santo, Cordeiro-Marino (1978) from Santa Catarina, Nunes et al. (2008) from Bahia. This species is easily recognized by its unique general appearance and the presence of characteristic papilliform cells along the distal portions. Three species are currently accepted taxonomically in the genus Dohrniella Funk: D. antillarum (Taylor) Feldmann-Mazoyer, D. nana Mayhoub and D. neapolitana Funk. The first is the only species that occurs in the Western Atlantic and differs from $D$. neapolitana by the absence of gland cells and from D. nana by having larger dimensions and a higher number of papilliform cells. The variety brasiliensis was proposed by Joly et al. (1963) to accommodate the specimens with one, rarely two, papilliform cells per branch cell, unilaterally arranged, on the outside of the branch, while $D$. antillarum has 1-3 papilliform cells per branch cell (Taylor \& Arndt 1929, as Actinothamnion antillarum). Joly et al. (1963) also described and illustrated tetrasporangial plants with tetrahedral tetrasporangia borne on special short branches. Details of female gametophyte of the Brazilian variety were studied for the first time by Joly \& Oliveira Filho (1971). Athanasiadis (1996) suggested that the Caribbean plants could be referred to as $D$. antillarum var. brasiliensis by the papilliform cell arrangement; however, the author pointed out that culture studies are required to determine the true status of this variety. In $D$. antillarum, reproductive structures are only known in the Brazilian variety, and the male gametophytes are illustrated here for the first time. Despite uncertainty about the validity of this variety (Stegenga \& Vroman 1987, Athanasiadis 1996, Schneider \& Searles 1997), we kept the specimens as D. antillarum var. brasiliensis.

Habitat: epiphytic on Bryothamnion seaforthii (Turner) Kützing and Haloplegma duperreyi Montagne and associated with Dipterosiphonia dendritica (C. Agardh) Schmitz.

\section{Rhodomelaceae}

Herposiphonia delicatula Hollenberg, Pacif. Sci. 22: 540. 1968. Type locality: Micronesia, Falas Island, Truk Island and Caroline Islands.

Figures 4a-i

Plants filamentous, ecorticated, brownish red, epiphytic, up to $1 \mathrm{~mm}$ high, attached to the host by uni- or multicellular rhizoids with simple or digitate tips, arising from distal end of pericentral cells. Prostrate axes of indeterminate growth, 87.5-100 $\mu \mathrm{m}$ wide, giving rise to erect determinate branches (d) and indeterminate branches (i), usually short, every three or four segments in the following patterns: $d / d / d / i$ or $d / d / d / d / i$. Determinate erect branches 
unbranched, 40-60 $\mu \mathrm{m}$ wide, composed of 13-15 segments longer than wide, with eight pericentral cells. Axial cells with approximately the same size as pericentral cells. Apices slightly attenuated.
Numerous well-developed trichoblasts in the apices of determinate branches, produced in successive segments, reaching up to $800 \mu \mathrm{m}$ wide, with a long basal cell, $112.5-200 \times 25-37.5 \mu \mathrm{m}$, with 3-4

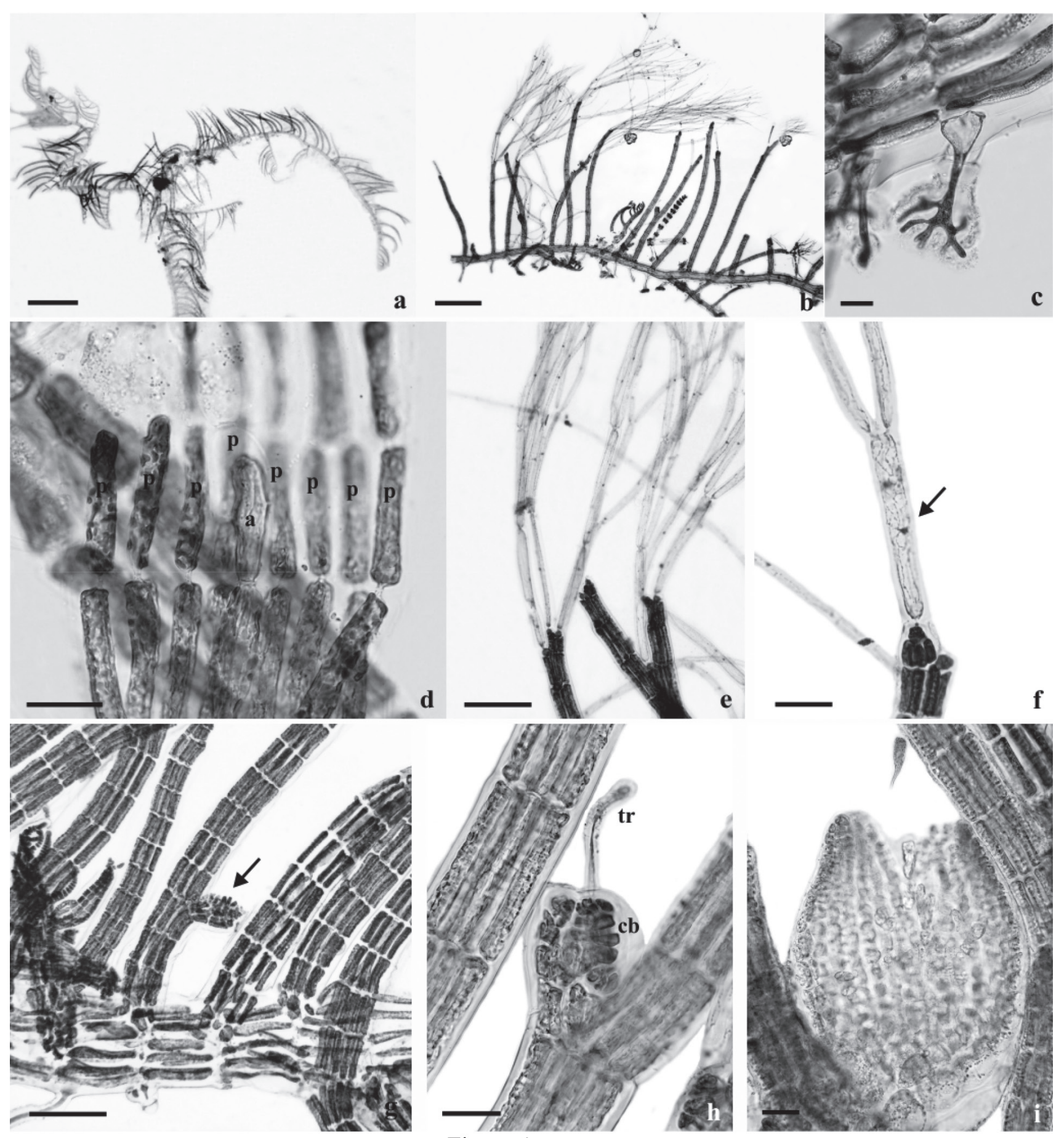

Figure 4. a-i. Herposiphonia delicatula. a. General habit of sterile plant. b. Detail of thallus showing trichoblasts well-developed and indeterminate branches produced every three segments. c. Rhizoid unicellular with digitate tip. d. Squash preparation of a determinate branch, showing the axial cell (a) and eight pericentral cells (p). e. Detail showing three trichoblasts produced per branch. f. Trichoblast basal cell (arrow). g. Procarp disposed in the lower half of erect branch (arrow). h. Detail of female plant showing the carpogonial branch (cb) and tricogine (tr). i. Mature cystocarp. Scale bars $=820 \mu \mathrm{m}$ (a), $250 \mu \mathrm{m}$ (b), $25 \mu \mathrm{m}$ (c, d, f, h, i), $100 \mu \mathrm{m}(\mathrm{e}, \mathrm{g})$. 
dichotomies. Usually three trichoblasts per branch and smaller than the branch which originated it. Procarps disposed in the lower half of erect branches, arising on the 3rd to 5th segment from the base. Cystocarps large, globose, with an evident apical pore, releasing pyriform carpospores. Tetrasporangia and male gametophytes were not found.

Material examined: BRAZIL. CEARÁ: Amontada, Icaraí de Amontada Beach, 31'6.37'S, 39³8'20.50'W, 17-III-2014, L.P. Soares (SP468777).

Remarks: our specimens closely resemble those described by Hollenberg (1968) from type collection, Schneider \& Searles (1991) from North Carolina, Abbott (1999) from the Hawaiian Islands, N'Yeurt \& Pairy (2010) from French Polynesia and Silva \& Fujii (2012) from Brazil. The red algal genus Herposiphonia Nägeli includes 56 accepted species distributed in tropical to warm-temperate regions of the world (Guiry \& Guiry 2017). In Brazil, six species of Herposiphonia have been cited from tropical to subtropical sites: $H$. bippinata Howe, $H$. delicatula, H. nuda Hollenberg, H. parca Setchell, H. secunda (C. Agardh) Ambronn and H. tenella (C. Agardh) Ambronn. Of these, $H$. secunda and $H$. tenella are widely reported along the Brazilian coast. Hollenberg (1968) stated that diagnostic characters of $H$. delicatula are the reproductive structures borne on the lower half of the determinate branches and that these branches are 35-50 $\mu \mathrm{m}$ wide and composed of 12-14 segments. This species is closest to H. tenella, and both exhibit considerable variation in branching pattern (Hollenberg 1968, Cribb 1983, Schneider \& Searles 1991). However, H. delicatula shows habit more slender, fewer periaxial cells and reproductive structures arising in the lower part of the branches.

Herposiphonia delicatula can also be confused with $H$. parca, as was noted by García et al. (2008) and Silva \& Fujii (2012), but the former has cystocarps on the basal half of determinate branches, while $H$. parca is stout, and the reproductive structures are strictly terminal. Silva \& Fujii (2012) reported the first occurrence of $H$. delicatula in Brazil from material collected in Rio Grande do Norte State. The authors mainly utilized the arrangement of trichoblasts, branch diameter and position of reproductive structures to differentiate the species from others occurring in Brazilian flora. The specimens herein analyzed were initially confused with representatives of $H$. parca, mainly by presence of trichoblasts profusely developed, reaching $800 \mu \mathrm{m}$ in length. However, $H$. parca is more robust, with erect axes up to $140 \mu \mathrm{m}$ wide, and its reproductive structures are distally disposed (Hollenberg 1968, García et al. 2008, N'Yeurt \& Pairy 2010, Silva \& Fujii 2012). Up to now, this is only the second citation of H. delicatula on the Brazilian coast.

Habitat: growing at intertidal zone, in tidal pools, as epiphytic on Gracilaria domingensis (Kützing) Sonder ex Dickie.

Laurencia aldingensis Saito \& Womersley, Aust. J. Bot. 22: 821. 1974. Type locality: Australia, Aldinga.

Figures 5a-h

Plants erect, reddish-pink, forming lax and delicate tufts, up to $6 \mathrm{~cm}$ high, attached to the substratum by a stoloniferous portion. Erect axes terete, $500-550 \mu \mathrm{m}$ wide, with sparse, alternate to irregular branching, producing branchlets up to $0.5 \mathrm{~mm}$ wide, disposed in open angle. In surface view, cortical cells arranged in longitudinal rows and connected to each other by secondary pit connections. In longitudinal section, outer cortical cell walls are not projected beyond the surface. In transverse section, two layers of pigmented cortical cells, quadratic, not arranged in palisade, and four layers of colorless medullary cells, rounded, becoming larger towards the center. Lenticular thickening absent. Each vegetative axial segment cuts off four pericentral cells. In longitudinal section of male branchlets, spermatangial pit is cup-shaped, with an axial cell row visible at base pit. Spermatangia arising in trichoblasts and spermatangial branches develop in the apical pit and terminate in vesicular sterile cells. Female gametophytes and tetrasporangial plants were not observed.

Material examined: BRAZIL. CEARÁ: Amontada, Icaraí de Amontada Beach, 3¹'6.37'S, 39³8'20.50'W, 17-III-2014, L.P. Soares (SP429274).

Remarks: the material from Ceará is consistent with the description of Saito \& Womersley (1974) and Womersley (2003), both from Australia, and Cassano (2009) from Brazil. The lax branching, branches disposed in open angle, and absence of lenticular thickening could all be useful characters to distinguish the species. All these attributes were evident in our specimens. Laurencia aldingensis was proposed by Saito \& Womersley (1974) from shallow reef pools of Aldinga, Southern Australia, and was characterized as entangled, epiphytic tufts on Fucales, with branches rarely more than $0.5 \mathrm{~mm}$ thick. For the first time, 
Carvalho et al. (2003) reported L. aldingensis on the Brazilian coast, Espírito Santo State, for chemical study of sesquiterpenes produced by the species.

In Brazil, L. aldingensis is morphologically and molecularly closest to $L$. catarinensis Cordeiro-
Marino \& Fujii, a species originally described from Santa Catarina in southern Brazil. Laurencia catarinensis forms cushion-like tufts, and its cortical cells are projected beyond the surface. Comparative molecular studies with samples from type locality,
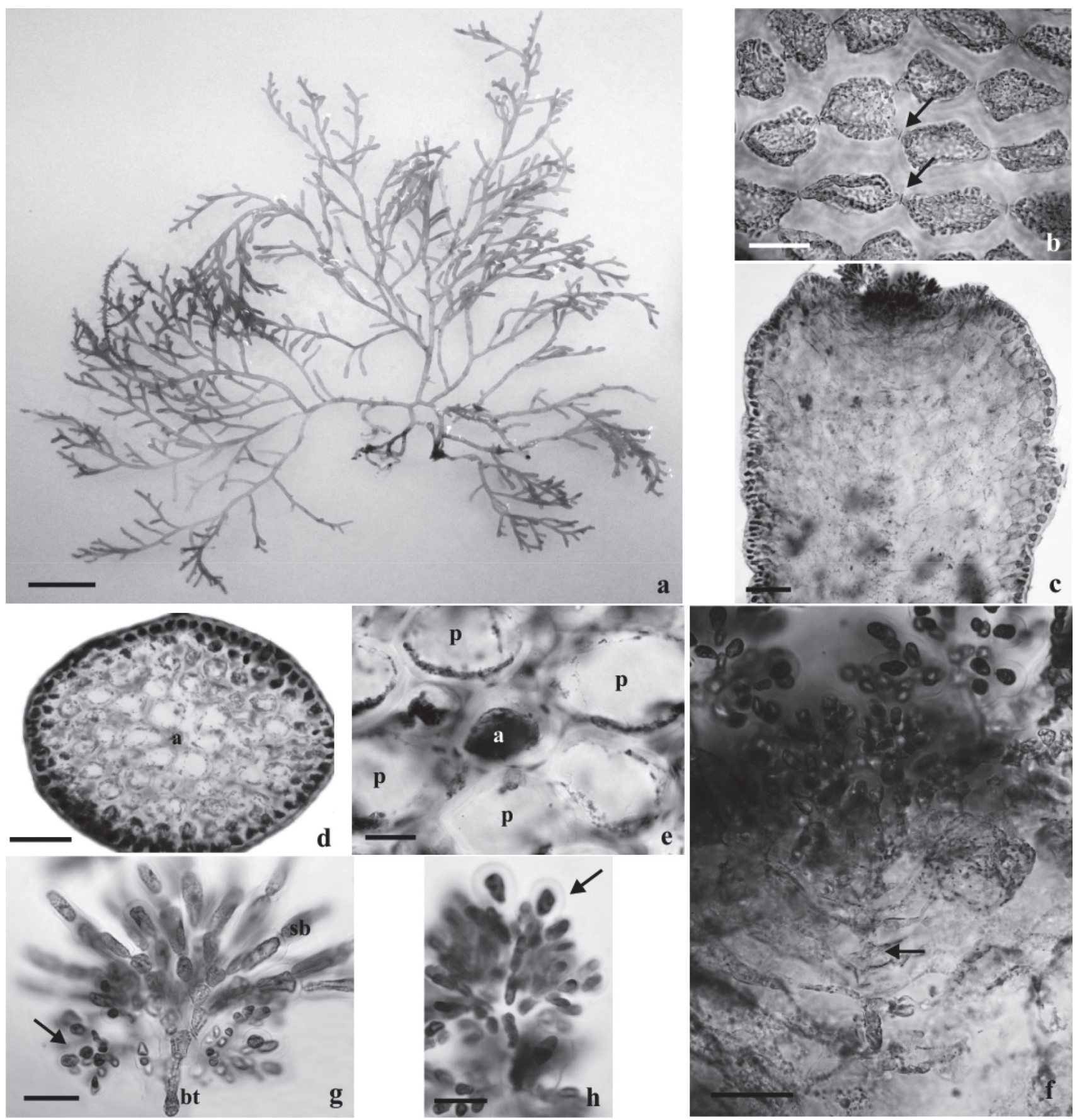

Figure 5. a-h. Laurencia aldingensis. a. General habit. b. Cortical cells in surface view, showing secondary pit-connections (arrows). c. Longitudinal section through a branchlet showing non-projecting cortical cells. d. Transverse section of the thallus, with an axial cell (a). e. Transverse section of the thallus showing an axial cell (a) and four pericentral cells (p). f. Longitudinal section through a branchlet showing spermatangial branches and an axial cell row discernible at the base (arrow). g. Detail of spermatangial branches (arrow) and sterile branch $(\mathrm{sb})$ on trichoblast $(\mathrm{bt})$. h. Detail of spermatangial branches showing terminal vesicular sterile cells (arrow). Scale bars $=$ $1 \mathrm{~cm}(\mathrm{a}), 25 \mu \mathrm{m}(\mathrm{b}, \mathrm{e}-\mathrm{h}), 100 \mu \mathrm{m}$ (c, d). 
Australia, are needed to certify the occurrence of L. aldingensis in Brazil. However, the chemical composition of the sesquiterpenes produced by this species, known as aldingenins, confirms its taxonomic autonomy (Carvalho et al. 2003, 2006).

Habitat: collected in shaded areas of tidal pools in the lower intertidal zone.

Laurencia oliveirana Yoneshigue, Taxonomie et ecologie des algues marines dans la region de Cabo Frio (Rio de Janeiro) Brésil, Université d'AixMarseille: 329. 1985. Type locality: Brazil, Rio de Janeiro.

Figures 6a-e

Plants suberect, reddish to brown, forming intricate mat-like tufts, up to $2 \mathrm{~cm}$ high, attached to the substratum by several small discoid holdfasts arising from basal branches. Erect axes terete, up to $500 \mu \mathrm{m}$ wide, with sparse, unilateral branching, producing branchlets clavate or cylindrical. In surface view, cortical cells connected to each other by secondary pit connections. In longitudinal section, outer cortical cell walls are not projected beyond the surface. In transverse section, 1-2 layers of pigmented cortical cells, quadratic and 3-4 layers of medullary cells.

Material examined: BRAZIL. CEARÁ: Fortaleza, Farol Beach, 342'27.13"'S, 38²8'7.95'W, 9-III-2012, L.P. Soares \& P.B. Carneiro (SP429261).

Remarks: our specimens, as described, agree with that studied by Fujii \& Sentíes (2005), Cassano (2009), Fujii et al. (2011) and Cassano et al. (2012).

The species was originally described by Yoneshigue (1985) from upper subtidal in Arraial do Cabo, Rio de Janeiro, and up to now, it has been considered endemic to the Brazilian coast. Laurencia oliveirana is mainly characterized by its small size, intricate habit and unilateral branching. This species resembles $L$. caraibica P.C. Silva by its dimensions and habit, but L. oliveirana is suberect and does not present anastomoses, while $L$. caraibica has a dorsiventral aspect and anastomoses between the branches. Phylogenetic studies based on $r b c \mathrm{~L}$ sequences carried out by Cassano et al. (2012) confirm this close relationship between L. caraibica and L. oliveirana, and both species were grouped in a monophyletic clade with genetic divergence of $2.3 \%$. Habitat: Collected in upper intertidal zone, forming mat-like tufts in the top reef, associated with turfs of Gelidiales.

\section{Colaconematales}

\section{Colaconemataceae}

Colaconema infestans (Howe \& Hoyt) Woelkerling, Rhodora 75: 89. 1973 $\equiv$ Acrochaetium infestans Howe \& Hoyt, Mem. New York Bot. Garden 6: 116. 1916. Type locality: United States, North Carolina.

Figures $7 \mathrm{a}-\mathrm{d}$

Plants filamentous, partially endophytic, uniseriate. Endophytic filaments entwining between the host cells, tortuous, profusely and irregularly branched. Cells elongate to irregular, contorted, $11-35 \times 3-7 \mu \mathrm{m}$. Few emergent filaments, up to $100 \mu \mathrm{m}$ long and 3 cells high, simple or sparsely branched. Cells cylindrical, up to $10 \times 6 \mu \mathrm{m}$. Apical hairs occasionally present, up to $50 \mu \mathrm{m}$ long. Monosporangia ovoid, $11-13 \times 6-8 \mu \mathrm{m}$, sessile or borne on short lateral branches, on erect filaments.

Material examined: BRAZIL. CEARÁ: Caponga, Cascavel Beach, 42'23.43”S, 38¹1'32.62"W, 31-VIII-2011, L.P. Soares, P.B. Carneiro \& M.T. Fujii (SP428950).

Remarks: the material analyzed has morphological characteristics that generally agree with the descriptions and illustrations of Taylor (1960), as Kylinia infestans (Howe \& Hoyt) Papenfuss, Schneider (1983), Dixon \& Irvine (1977) and Schneider \& Searles (1991), all as Audouinella infestans (Howe \& Hoyt) Dixon, Sansón et al. (2002) as Acrochaetium infestans Howe \& Hoyt and Woelkerling (1973). Guimarães (2006) made the first reference to C. infestans in Brazil from Espírito Santo State, which was found as endophytic in Chondracanthus teedei (Mertens ex Roth) Fredericq, and the specimens from Ceará are consistent with those illustrated by the author. Colaconema infestans can also occur as endozoic in hydroids or sponges (Taylor 1960, Dixon \& Irvine 1977, Schneider 1983, Sansón et al. 2002, Hwang \& Kim 2011). The species was easily recognized by the endophytic, tortuous filaments and short erect axes. Its small size and habitat make this species easy to overlook in most floristic surveys. For this reason, $C$. infestans is probably far more widespread than current reports indicate.

Habitat: Endophytic in Acanthophora muscoides (Linnaeus) Bory.

\section{Gelidiales}

\section{Gelidiellaceae}


Gelidiella flabella G.H. Boo \& Le Gall, Taxon 65: 974. 2016. Type locality: Madagascar, Flacourt.

Figures $7 \mathrm{e}-\mathrm{i}$

Plants erect, vinaceous, tufted, up to $3 \mathrm{~cm}$ high, attached to the substratum by independent unicellular rhizoids, arising from stoloniferous prostrate axes terete. Erect branches flattened, up to $2 \mathrm{~mm}$ wide, ligulate, lanceolate, generally undulate, with a slight thickening in the central region, like a midrib. Branching sparse and irregular. Apices obtuse, domeshaped apical cell. In cross section, branches with 1-3 layers of small, rounded, pigmented cortical cells and 5-8 layers of elongated, thick-walled medullary cells. Rhizoidal filaments (rhizines) absent. Reproductive structures were not found.

Material examined: BRAZIL. CEARÁ: Trairi, Guajiru Beach, 3¹4'0.16”S, 39¹4'26.22”W, 30-VIII-2011, L.P. Soares, P.B. Carneiro \& M.T. Fujii (SP468802), Fortaleza, Farol Beach, 342’27.13”'S, 38²8’7.95”W, 9-III-2012, L.P. Soares \& P.B. Carneiro (SP468800).

Remarks: the specimens described agree with previous descriptions of G. flabella, such as Dawson (1953) to the
Mexican Pacific (type locality) and Shimada \& Masuda (1999) to Japan, both as G. ligulata Dawson. Three species of Gelidiella Feldmann \& Hamel are known from the Brazilian coast: G. acerosa (Forsskål) Feldmann \& Hamel, G. hancockii Dawson and G. flabella. Habit and size of thallus are used to distinguish them. G. acerosa shows a tough thallus with pinnate branching, and $G$. hancockii forms small tufts with cylindrical branches, unbranched or unilaterally branched (Ugadim 1974, Norris 2014). Small size, flattened axes and distinctive ligulate branches characterize $G$. flabella quite well. Boo et al. (2016) revised the classification of the Gelidiellaceae, based on molecular and morphological data and described G. flabella to accommodate the specimens previously recognized as G. ligulata from Brazil, Japan and Madagascar.

Habitat: specimens forming delicate tufts buried in the sand, in shallow tidal pools or in reef plateau, in the middle of the intertidal zone.

\section{Gigartinales}

\section{Gigartinaceae}

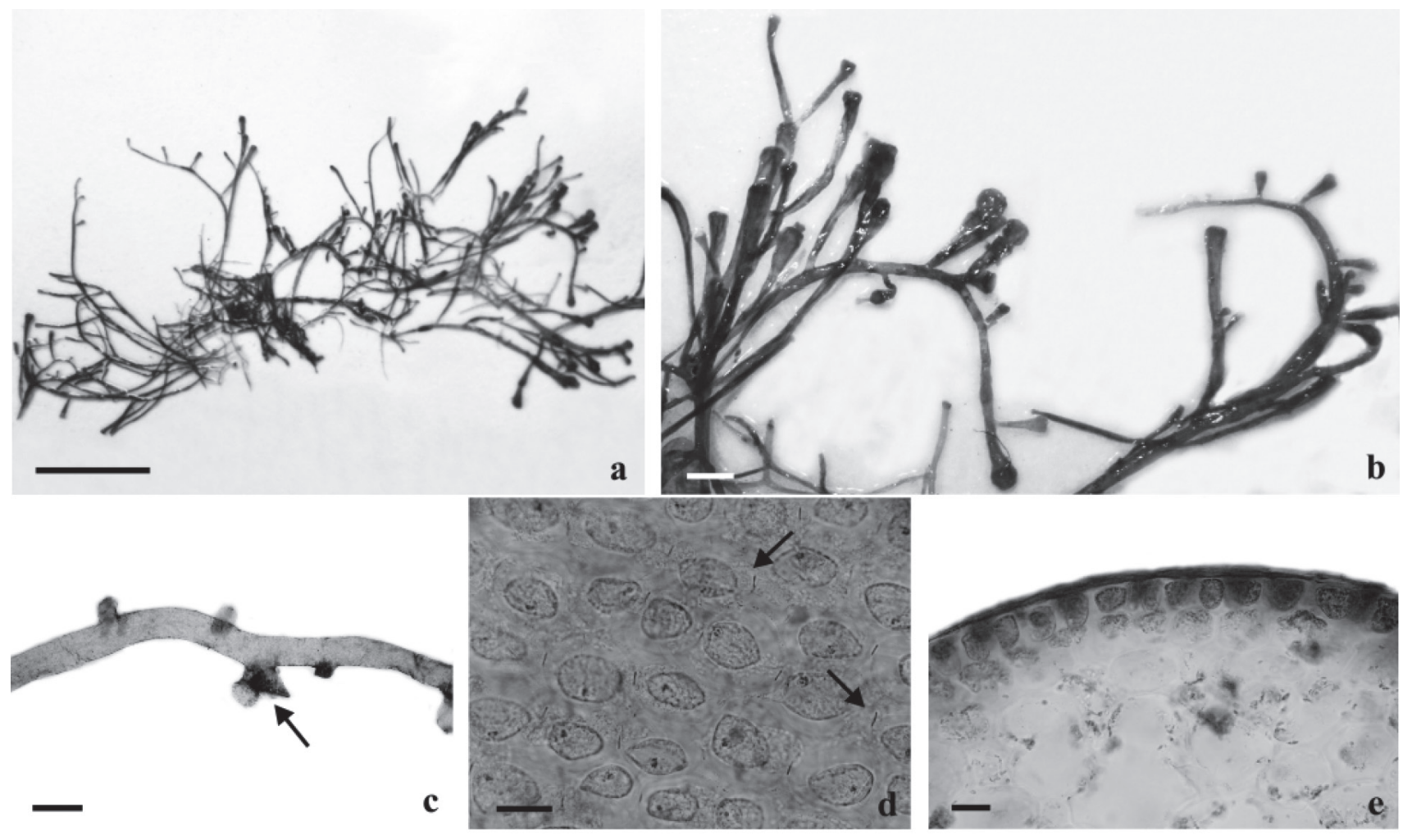

Figure 6. a-e. Laurencia oliveirana. a. General habit. b. Detail of branching. c. Basal portion with discoid holdfast (arrow). d. Cortical cells in surface view, showing secondary pit-connections (arrows). e. Transverse section of the thallus, showing cortical cells not arranged in palisade. Scale bars $=1 \mathrm{~cm}(\mathrm{a}), 2 \mathrm{~mm}(\mathrm{~b}), 1 \mathrm{~mm}(\mathrm{c}), 25 \mu \mathrm{m}(\mathrm{d}, \mathrm{e})$. 
Chondracanthus saundersii Schneider \& Lane, Phycologia 44: 77. 2005. Type locality: Bermuda Island, Hamilton Parish.

Figures 8a-h

Plants erect, vinaceous, tufted, flaccid, lubricous, up to $8 \mathrm{~cm}$ high, attached to the substratum by a small discoid holdfast and several rhizoidal pads scattered along the thallus. Axes terete at basal portions, soon becoming compressed. Branching usually irregular to alternate, but also opposite to unilateral. Branches up to $1 \mathrm{~mm}$ wide, often recurved and tapered, bearing numerous short branchlets throughout, up to $1 \mathrm{~mm}$ long. Multiaxial construction. In cross section, 4-5 layers of small, rounded to ovoid cortical cells and medulla composed of loosely arranged filaments. Numerous elongated, stellate cells between cortical cells and medullary filaments. Cystocarps globose scattered in upper branches. Tetrasporangia and male gametophytes were not observed.

Material examined: BRAZIL. CEARÁ: São Gonçalo do Amarante, Taíba Beach, 330'31.01'S, 3853'14.35'W, 27-VI-2013, L.P. Soares (SP428984); Caucaia, Pacheco Beach, 341'13.49”'S, 38³7'52.54”W, 1-IX-2011, L.P. Soares \& M.T. Fujii (SP428985); Dois
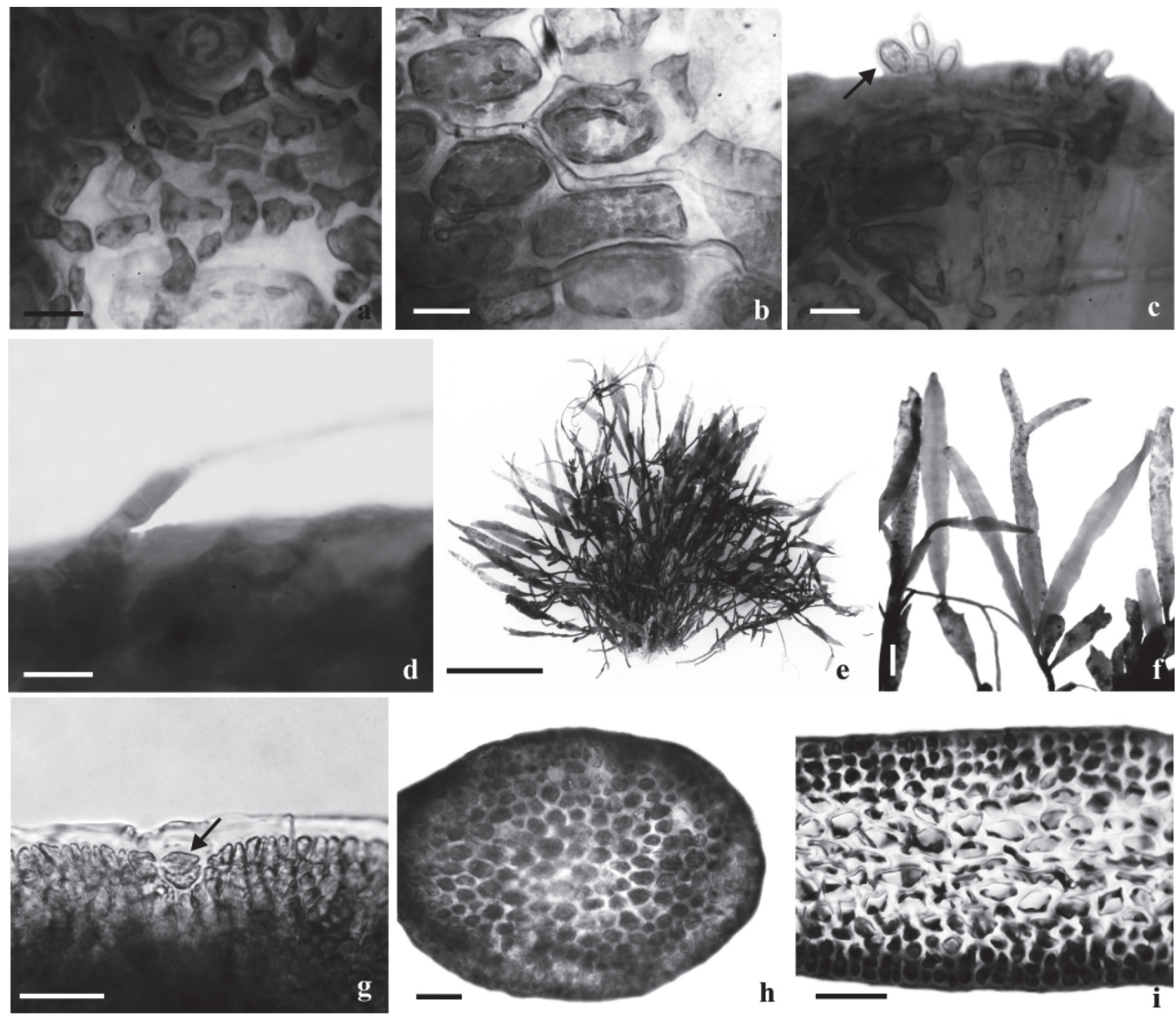

Figure 7. a-d. Colaconema infestans. a. Habit of endophytic filaments in Acanthophora muscoides. b. Detail of endophytic filaments showing the contorted cells. c. Detail showing a short erect filament with a monosporangium (arrow). d. Detail of a single unicellular hair. e-i. Gelidiella flabella. e. General habit. f. Detail of sparse and irregular branching; note the slight central thickening, like a midrib. g. Surface view of apex, showing apical cell (arrow). h. Cross section in the basal region of an erect branch. i. Cross section in the middle region of an erect branch. Scale bars $=10 \mu \mathrm{m}(\mathrm{a}-\mathrm{d}), 1 \mathrm{~cm}(\mathrm{e}), 1.6 \mathrm{~mm}(\mathrm{f}), 25 \mu \mathrm{m}$ (g-i). 

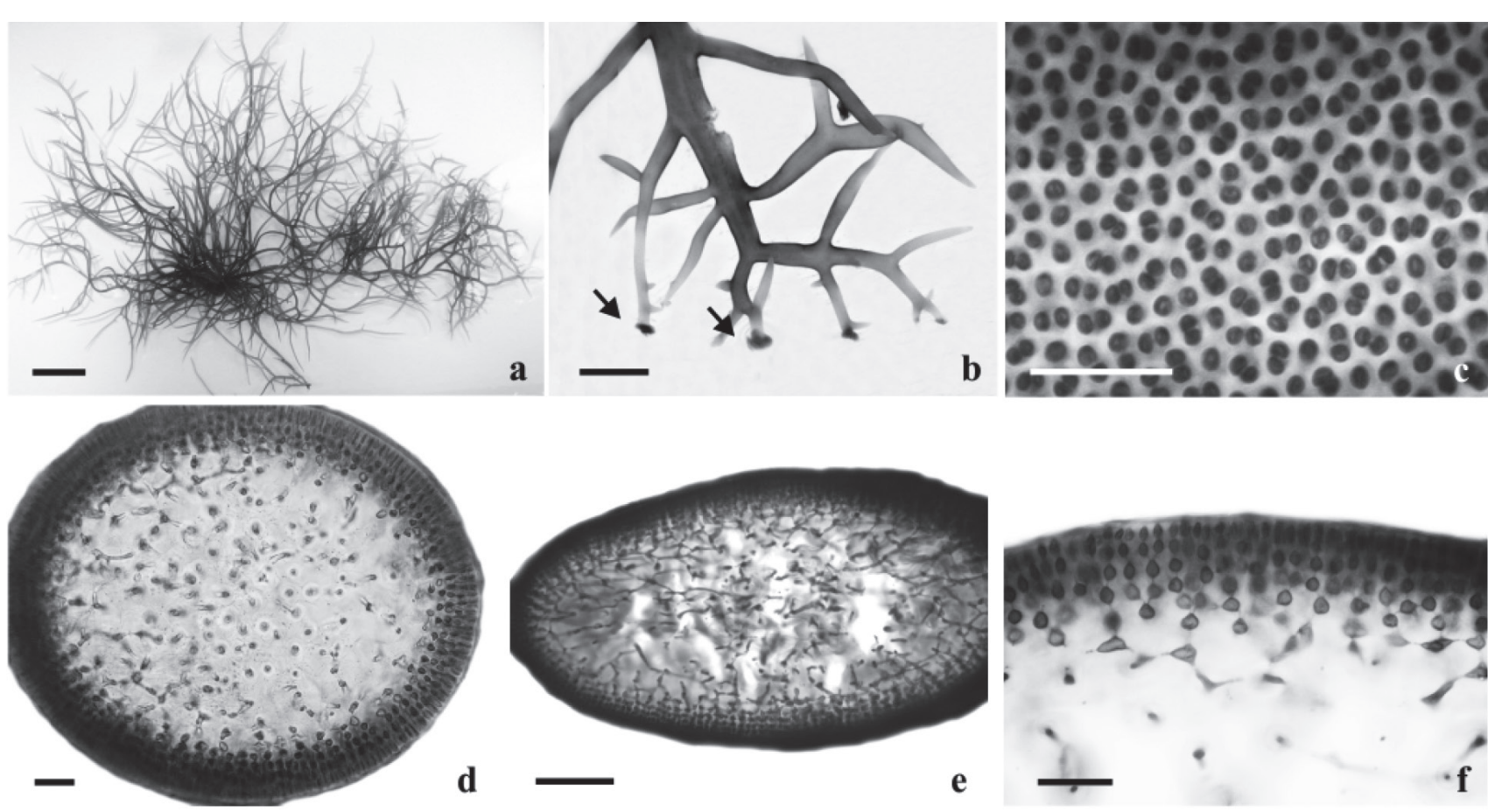

d

.
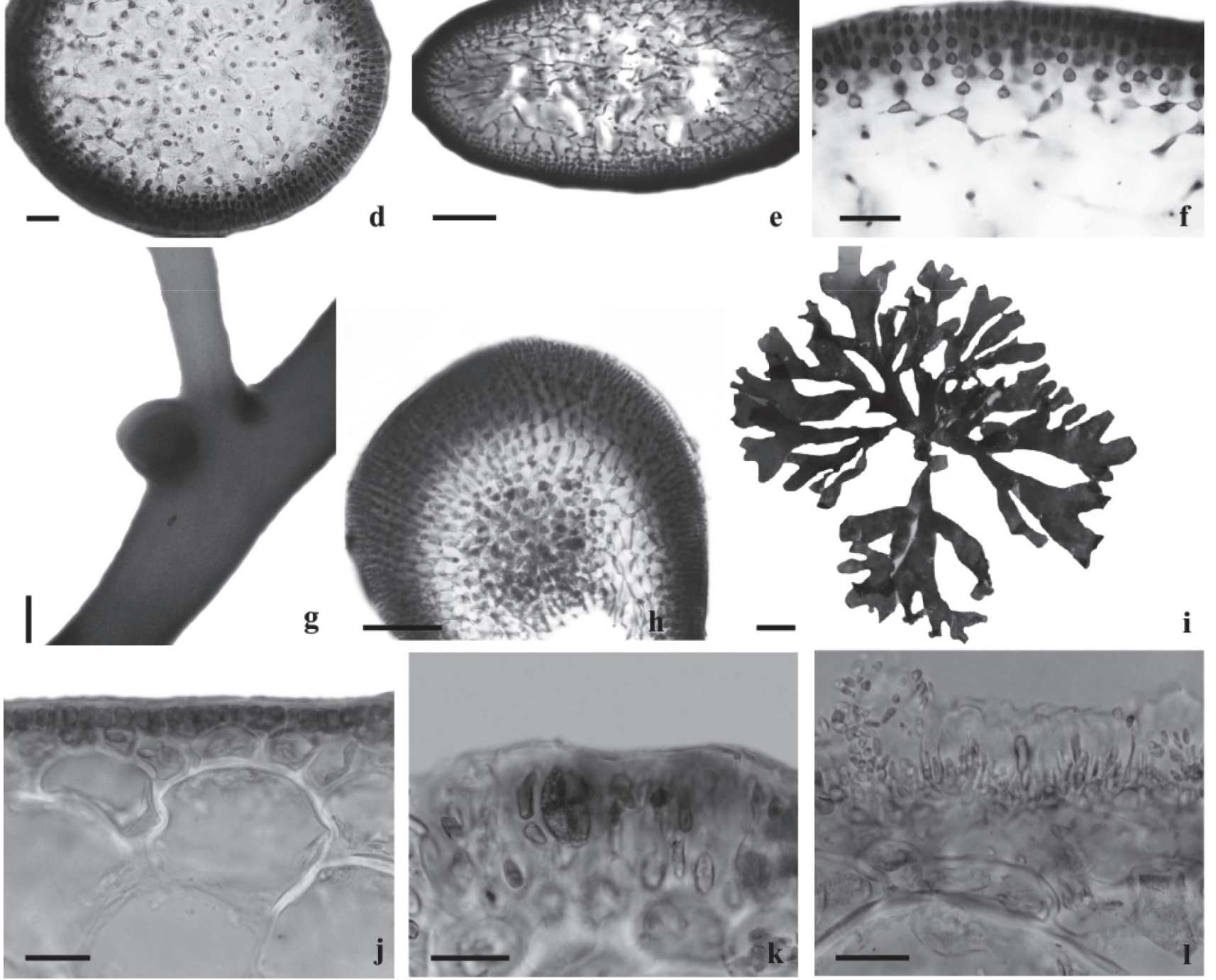

Figure 8. a-h. Chondracanthus saundersii. a. General habit. b. Detail of compressed thallus, with apical fixation pads (arrows). c. Surface view showing rounded to ovate cortical cells. $d$. Transverse section of the basal region. e. Transverse section of the median region. $f$. Transverse section showing detail of outer and inner cortical cells. g. Cystocarp in surface view. h. Transverse section of cystocarp showing large central carposporangial mass surrounded by medullary filaments. i-l. Gracilaria hayi. i. General habit. j. Transverse section of the median region, showing abrupt transition between cortical and medullary cells. $\mathrm{k}$. Transverse section of tetrasporophyte, showing cruciate tetrasporangia. 1. Transverse section of spermatangial thallus, showing shallow textorii-type conceptacles. Scale bars $=1 \mathrm{~cm}(\mathrm{a}, \mathrm{i}), 1.6$ $\mathrm{mm}(\mathrm{b}), 25 \mu \mathrm{m}(\mathrm{c}, \mathrm{f}, \mathrm{j}-1), 100 \mu \mathrm{m}(\mathrm{d}, \mathrm{e}, \mathrm{h}), 200 \mu \mathrm{m}(\mathrm{g})$. 
Coqueiros Beach, 341'18.40”S, 38³6'38.61”W, 28-VIII-2011, L.P. Soares \& M.T. Fujii (SP428986); 25-VI-2013, L.P. Soares (SP428987).

Remarks: our specimens have morphological features matching those reported for $C$. saundersii from type locality (Schneider \& Lane 2005), Cuba (Cabrera et al. 2009) and Brazil (Soares \& Fujii 2012). However, the Brazilian plants are not fully flattened as described by Schneider \& Lane (2005); rather, they are cylindrical at base, soon becoming compressed to flattened in middle portions of the thallus. Based on morphological characters and plastid $r b c \mathrm{~L}$ sequences, Schneider \& Lane (2005) proposed C. saundersii to accommodate specimens from Chondracanthus Kützing with narrow, flattened axes, lubricous texture and medulla with loosely entangled filaments. On this occasion, the authors included Brazil in the distribution range of C. saundersii from specimens collected in Rio de Janeiro in 1925 by W.L. Schmitt, as Gelidium corneum (Hudson) Lamouroux. Later, Cabrera et al. (2009) confirmed the occurrence of $C$. saundersii in Cuba and also described tetrasporophytic plants. The genus Chondracanthus contains approximately 20 species currently recognized, and four of them are known from the Brazilian coast: $C$. acicularis (Roth) Fredericq, C. elegans (Greville) Guiry, C. saundersii and C. teedei (Mertens ex Roth) Kützing. These species are distinguished by thallus shape, size, branching pattern and internal structure. Reported only along the Brazilian south and southeast coast (Baptista 1977, Cordeiro-Marino 1978), C. elegans differs from $C$. saundersii by the strap-shaped thallus, copiously branched. Although Braga (1986) suggested that $C$. elegans, as Gigartina elegans Greville, should be treated as a synonym of $C$. teedei, they are currently considered distinct entities. Chondracanthus acicularis and $C$. teedei are widely reported along the Brazilian coastline and differ from $C$. saundersii by their terete thallus and more robust branching pattern, respectively. The great morphological resemblance to the very common species $C$. acicularis may have resulted in the scarcity of records of $C$. saundersii to Brazil. The presence of diagnostic features, including lubricous texture, flattened thallus, recurved axes and loose medullary filaments, give evidence in support of the maintenance of the specimens from Ceará in C. saundersii.

Habitat: plants with a distinctive mat-like habit, with expressive biomass, intermingled with Gelidium crinale (Hare ex Turner) Gaillon, epilithic throughout the eulittoral zone, but mostly in the upper eulittoral, on top of tidal pools.

\section{Gracilariales}

\section{Gracilariaceae}

Gracilaria hayi Gurgel, Fredericq \& Norris, Taxonomy of Economic Seaweeds with reference to the Pacific and other locations IX: 178. 2004. Type locality: Panama, Galeta Point.

Figures 8i-1

Plants erect, reddish to reddish brown, fleshy, $5.5-11 \mathrm{~cm}$ high, attached to the substratum by a small discoid holdfast. Thalli flattened, strap-like, with a short basal stipe, up to $1 \mathrm{~cm}$ long, from which arise erect axes 4-24 mm wide, irregularly branched. More robust specimens with dichotomies, or even polytomies, giving them a flabellate, fan aspect. Some branches with cuneate base. Margins smooth to slightly undulate. Apices rounded, several heartlike. In transverse section, base of thallus with up to 5 layers of ovate to quadrate cortical cells and up to 3 layers of large medullary cells, polygonal in shape to slightly flattened, with thickened walls. Middle section, 1-2 layers of small cortical cells and up to 4 layers of large medullary cells, rounded, thick-walled. Sharp transition between cortical and medullary region. Tetrasporangia cruciately divided, scattered on both surfaces of thallus. Spermatangia in shallow conceptacles, textorii type, on both surfaces of thallus. Female gametophytes were not observed.

Material examined: BRAZIL. CEARÁ: Caucaia, Pacheco Beach, 341'13.49'S, 38³7'52.54”W, 28-VI-2013, L.P. Soares (SP428116), Dois Coqueiros Beach, 341'18.40”'S, 38³6'38.61'W, 25-VI-2013, L.P. Soares (SP428108), Fortaleza, Meireles Beach, 343'23.71'"S, 38²9'20.61'”, 8-III-2012, L.P. Soares (SP428113), Cascavel, Caponga Beach, 42'23.43”S, 38¹1'32.62"W, 31-VIII-2011, L.P. Soares, P.B. Carneiro \& M.T. Fujii (SP428114).

Remarks: our material is similar to that described and illustrated by Schneider (1975) and Schneider \& Searles (1991), both as G. mammillaris (Montagne) Howe, Hay \& Norris (1984), as G. cuneata, Gurgel et al. (2004) and Dawes \& Mathieson (2008). Gracilaria hayi shows great morphological variation, resembling numerous species of the genus, such as G. cearensis (Joly \& Pinheiro) Joly \& Pinheiro, G. cuneata and G. curtissiae J. Agardh. The broad thallus, 
flabellate aspect, cordate axes, dichotomies in several orders and absence of marginal proliferations are useful features for the identification of G. hayi. The identification of only one specimen or young plants can be difficult, and in this case, the use of molecular makers in needed.

On the Ceará coast, the identity of $G$. hayi was confirmed through $r b c \mathrm{~L}$ sequences (GenBank accession numbers KT881561, KT881562), which indicated the expansion of its distribution range. Soares et al. (2015) recently reported a comparative study of closely related species based on morphological and molecular data. These authors showed that $r b c \mathrm{~L}$ sequences of specimens from Ceará are 100\% identical to sequences of $G$. hayi from type locality and that it is morphologically and genetically more closely related to $G$. cearensis. The morphological resemblance of $G$. hayi with other flattened species may be the probable cause of its late reference to the Brazilian coast, and it is probably far more widespread than Florida, Panama and Brazil, as indicated in studies thus far reported.

Habitat: Gracilaria hayi is a common species on the beaches from the metropolitan region of Fortaleza, collected as drift or epilithic, forming isolated tufts in the intertidal zone.

Gracilariopsis silvana Gurgel, Fredericq \& Norris, Hidrobiológica 13(1): 61. 2003. Type locality: Venezuela, Barranquilla Beach.

Figures 9a-f

Plants erect, reddish brown, 4-19 $\mathrm{cm}$ high, attached to the substratum by a small discoid holdfast. Thalli terete at base, soon becoming flattened, strap-like, 1-14 mm wide. Axes broader in the middle portions of the thallus where the branches are more numerous. Several delicated and lanceolated proliferations. Branching dichotomous, subdichotomous to irregular, from basal region. Narrower branches toward the apices, with short branchlets, up to $5 \mathrm{~mm}$ long, irregularly disposed. Some apical branches bearing 3-5 lanceolated branchlets. Ultimate branches slightly twisted, usually with acute and bifurcate apices. In transverse section, base of the thallus with numerous layers of small cortical cells, recovered by a thick cuticle and 3-5 layers of medullary cells with high concentration of floridean starch grains. In middle section, 350-450 $\mu \mathrm{m}$ thick, 1-2 layers of small isodiametric cortical cells and 5-7 layers of compressed medullary cells, 180-220 $\times$ 80-100 $\mu \mathrm{m}$. Gradual transition between cortical and medullary region, except in the apices, where a sharp transition occurs, and the medullary cells are less compressed and larger than those of middle portions. Tetrasporangia cruciately divided, scattered on both surfaces of thallus. Male and female gametophytes were not found.

Material examined: BRAZIL. CeArÁ: Caucaia, Pacheco Beach, 341'13.49'S, 38³7'52.54”W, 28-VI-2013, L.P. Soares (SP428130), Dois Coqueiros Beach, 341'18.40'S, 38³6’38.61'W, 25-VI-2013, L.P. Soares (SP428124).

Remarks: the specimens studied match the description given by Gurgel et al. (2003), but tetrasporangial specimens were seen for the first time. Twenty-four species are currently accepted in Gracilariopsis Dawson worldwide. Two of them are known from the Brazilian coast: G. tenuifrons and G. silvana. The former is widely recorded in Brazil and is mainly distinguished by its slender, cylindrical thallus. Gracilariopsis silvana, the first flat species recognized in Gracilariopsis, was described and illustrated by Gurgel et al. (2003) based on morphological and $r b c \mathrm{~L}$ analysis. This rarely reported species is mainly characterized by flattened thallus, sometimes slightly undulated, subdichotomously or irregularly branched, with branches decreasing in width distally. Besides these features, highlighted in the original description, our material showed most branches arising from the middle portions of the thallus and several bifurcate and twisted apices. In the absence of male or female plants, or even molecular data, it can be difficult to distinguish $G$. silvana from similarly flattened species of Gracilaria Greville. The two genera can be differentiated by the spermatangia superficial (chorda type), not in cavities, and absence of nutritive filaments between the gonimoblasts and pericarp in Gracilariopsis. Although only tetrasporophytic plants have been examined, the $r b c \mathrm{~L}$ sequences obtained (unpublished data) confirmed the presence of this species in the region. Additional studies will probably reveal the occurrence of misidentifications along the Brazilian coast, which can be the reason for underestimating $G$. silvana reports.

Habitat: collected forming tufts in tidal pools, associated with Gracilaria species.

\section{Halymeniales}

\section{Halymeniaceae}




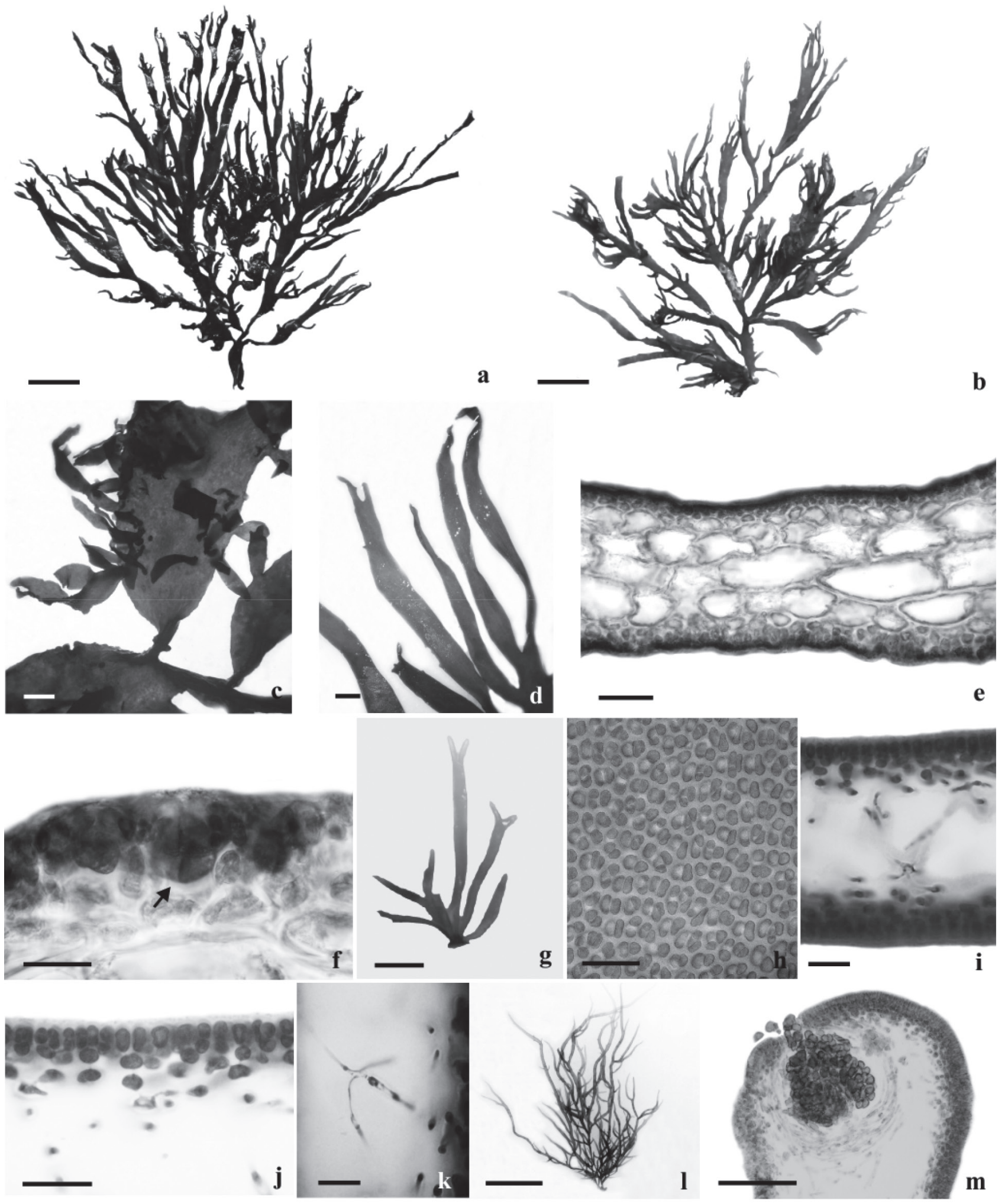

Figure 9. a-f. Gracilariopsis silvana. a, b. Range of habit variation. c. Branches with proliferations. d. Detail showing lanceolate and tortuous branchlets. e. Transverse section of the median region, showing gradual transition between cortical and medullary cells. f. Transverse section of tetrasporophyte, showing cruciate tetrasporangia (arrow). g-k. Grateloupia dichotoma. g. General habit. h. Surface view of thallus. i. Transverse section of thallus. j. Transverse section showing outer and inner cortical cells. k. Transverse section showing a stellate cell in the outer medulla. 1-m. Grateloupia filiformis. 1. General habit. m. Transverse section of cystocarp; note the ostiole not protruding. Scale bars $=1 \mathrm{~cm}(\mathrm{a}, \mathrm{b}, \mathrm{g}, \mathrm{l}), 1.6 \mathrm{~mm}$ (c, d), $100 \mu \mathrm{m}(\mathrm{e}, \mathrm{m}), 25 \mu \mathrm{m}(\mathrm{f}, \mathrm{h}, \mathrm{i}-\mathrm{k})$. 
Grateloupia dichotoma J. Agardh, Algae maris Mediterranei et Adriatici: 103. 1842. Type locality: France, Nice.

Figures 9g-k

Plants erect, greenish-red, lubricous texture, $23 \mathrm{~mm}$ high and $0.8-2 \mathrm{~mm}$ wide, attached to the substratum by a small discoid holdfast, $2 \mathrm{~mm}$ wide. Flattened erect axes, 120-250 $\mu \mathrm{m}$ thick, with smooth margins, without proliferations, unbranched below and sparsely, dichotomously branched above, wider in the middle portions. Branching concentrated at apex. Bifurcate and tapered tips. Multiaxial construction. In transverse section, outer cortex 1-2 cells thick, ovoid to cylindrical, inner cortex 2-3 cells thick, rounded to irregular in outline. Medullary filaments loosely interlaced, 2.7-7.5 $\mu \mathrm{m}$ wide, sparse, randomly arranged, branched, usually with stellate cells in the outer medulla. Reproductive structures were not observed.

Material examined: BRAZIL. CEARÁ: São Gonçalo do Amarante, Taíba Beach, 3³0’31.01"S, 38 53'14.35”'W, 27-VI-2013, L.P. Soares (SP428950).

Remarks: the specimen studied is very similar to Brazilian plants described in Cordeiro-Marino (1978), Ferreira-Correia (1987) and Guimarães (1990). On the other hand, the material analyzed by Taylor (1960) and Azevedo (2016) is described as having irregular branching and small marginal proliferations, which were not observed in our specimens. The small size and dichotomous apices characterize $G$. dichotoma very well. Phylogenetic analysis conducted by De Clerck et al. (2005a) showed that Brazilian specimens identified as $G$. dichotoma are another species, given that samples from Brazil and type locality, France, grouped in distinct clades. Recently, based on morphology and $r b c \mathrm{~L}$ sequences, Gargiulo et al. (2013) reported that the genus Grateloupia C. Agardh, as currently circumscribed, should be segregated. These analyses do not support the maintenance of G. dichotoma in the genus Grateloupia, and thus the authors proposed the new combination Dermocorynus dichotomus (J. Agardh) Gargiulo, Morabito \& Manguishi to accommodate the specimens previously identified as $G$. dichotoma.

However, the results obtained by Azevedo (2016) reveal that $G$. dichotoma from Brazil does not correspond to D. dichotomus, grouping instead with G. filicina (Lamouroux) C. Agardh, the generitype of Grateloupia, indicating that it is probably a new species of this genus. This corroborates the results shown by De Clerck et al. (2005a), and for this reason, the nomenclature was kept herein as G. dichotoma.

Habitat: grows in association with $G$. filicina (Lamouroux) C. Agardh, in shallow intertidal pools.

Grateloupia filiformis Kützing, Species Algarum: 731. 1849. Type locality: Peru.

Figures $91 \mathrm{~m}$

Plants erect, reddish to purplish-red, soft and lubricous texture, $3-6 \mathrm{~cm}$ high, up to $1 \mathrm{~mm}$ wide, attached to the substratum by a small discoid holdfast, 1-2 mm wide. Terete to slightly compressed erect axes, 280-560 $\mu \mathrm{m}$ thick, irregularly branched, sometimes unilateral. Narrower branches towards the apices, tapered, commonly tortuous. Several proliferations alternately to irregularly disposed. Multiaxial construction. In transverse section, outer cortex up to 3 cells thick, the outermost cells ovate, inner cortex up to 4 cells thick, quadratic to rectangular. Medullary filaments scarce, loosely interlaced. Cystocarps spherical, scattered over thallus surface, 150-280 $\mu \mathrm{m}$ wide, including pericarp, slightly prominent, ostiole not protruding. Tetrasporangia and spermatangia were not found.

Material examined: BRAZIL. CEARÁ: Caucaia, Pacheco Beach, 341'13.49'S, 38³7'52.54”W, 28-VI-2013, L.P. Soares (SP428957).

Remarks: our material agrees well with the original description of the species in Kützing (1849) and Brazilian specimens in Guimarães (1990), as Grateloupia sp. Grateloupia filiformis is similar in habit to G. filicina, usually found sharing the same habitat. In the studied flora, it can be distinguished by its more slender thallus, sparse and irregular branching, terete to compressed axes and branches with tapered and tortuous apices. According to Azevedo (2016), rbcL sequences of G. filiformis from Brazil formed a well-supported monophyletic clade with $G$. orientalis Lin \& Liang from China and Brazil, as sister species. However, sequences from type locality (Peru) are needed to resolve its true taxonomic and phylogenetic status.

Habitat: grows individually in calm waters, collected in association with G. filicina, forming slender tufts in the upper eulittoral.

\section{Rhodymeniales}

\section{Lomentariaceae}


Ceratodictyon planicaule (Taylor) Wynne, Nova Hed. Beih. 140: 108. 2011 W Wurdemannia miniata (Sprengel) Feldmann \& Hammel var. planicaulis Taylor, Papers Mich. Acad. Sci. Arts \& Lett. 28: 158. 1943. Type locality: Haiti, Jérémie.

Figures 10a,b

Plants erect, greenish-brown, up to $8 \mathrm{~cm}$ high, tough, wiry, forming entangled tufts, attached to the substratum by a cylindrical stoloniferous portion. Multiaxial construction. Erect axes cylindrical at base, up to $380 \mu \mathrm{m}$ in diameter, becoming compressed distally, up to $280 \mu \mathrm{m}$ thick and $490 \mu \mathrm{m}$ wide. Branching sparse and irregular. In transverse section, 1-2 layers of small cortical cells, ovate, with 7.5-12.5 $\times 2.5-5 \mu \mathrm{m}$ and 8-9 layers of rounded medullary cells, larger towards the cortical region. Reproductive structures were not seen.

Material examined: BRAZIL. CEARÁ: Caucaia, Pacheco Beach, 341'13.49'S, 38³7'52.54'W, 28-VI-2013, L.P. Soares (SP468814).

Remarks: the plants agree with those described in Joly (1965), as Gelidiopsis gracilis (Kützing) Vickers from Brazil, Littler \& Littler $(1997,2000)$ from Belize, Schneider \& Lane (2005) from Bermuda and Dawes \& Mathieson (2008) from Florida, all these as Gelidiopsis planicaulis (Taylor) Taylor. Ceratodictyon planicaule was originally described as $W$. miniata var. planicaulis by Taylor (1943) in an account of the seaweeds from Haiti. The new variety was mainly characterized as rhizomatous at base, irregularly alternate branched, clearly compressed near the center of plant. Later, Taylor (1960) transferred this taxon to the genus Gelidiopsis Schmitz, as G. planicaulis. Norris (1987) conducted a detailed morphological study in Gelidiopsis and Ceratodictyon Zanardini species from South Africa and observed that no reproductive characters separated these two genera. It was then proposed that Gelidiopsis should be merged into Ceratodictyon. However, Price \& Kraft (1991) did not accept this position, arguing that these genera should be maintained as distinct taxa, even though closely related. Based on phylogenetic analyses of the order Rhodymeniales, Le Gall et al. (2008) corroborated the interpretation of Norris (1987), showing that Gelidiopsis is congeneric to Ceratodictyon. Wynne (2011), in light of the finding obtained by Le Gall et al. (2008), proposed the new combination Ceratodictyon planicaule.
Nine species have so far been assigned to Ceratodictyon, and five of them are recognized in Brazil: C. intricatum (C. Agardh) Norris, $C$. planicaule, C. repens (Kützing) Norris, C. scoparium (Montagne \& Millardet) Norris and C. variabile (J. Agardh) Norris. The taxonomic distinction between C. planicaule and C. variabile is controversial in the literature. These two species were already considered synonyms by Norris (1987), but differences found by Littler \& Littler $(1997,2000)$ justify the maintenance of these two entities. Ceratodictyon planicaule differs from $C$. variabile in its irregular branching and compressed thallus in upper portions. These attributes were evident in plants collected on the Ceará coast. The absence or presence of anastomoses, wide thallus and branching pattern are useful characters to separate species of the genus.

Habitat: collected forming entangled tufts in the upper eulittoral.

Ceratodictyon scoparium (Montagne \& Millardet) Norris, S. Afr. J. Bot. 53: 245. $1987 \equiv$ Gelidium scoparium Montagne \& Millardet, Bot., Crypt., Algues: 13. 1862. Type locality: Indian Ocean, Reunion Island.

Figures 10c-f

Plants erect, reddish-brown to blackish, 2-4 cm high, tough, wiry, forming tufts, attached to the substratum by rhizoids arising from a cylindrical stoloniferous portion. Multiaxial construction. Erect axes cylindrical at base, $250-340 \mu \mathrm{m}$ in diameter, becoming compressed distally, up to $200 \mu \mathrm{m}$ thick and $500 \mu \mathrm{m}$ wide, denuded in lower portions. Branching dichotomous, especially in the apices. In transverse section, 1-3 layers of small cortical cells, spherical, ovate to irregular, 5-12.5 $\times 2.5-7.5 \mu \mathrm{m}$ and up to 11 layers of medullary cells. Reproductive structures were not observed.

Material examined: BRAZIL. CeArÁ: Caucaia, Pacheco Beach, 341'13.49”S, 38³7'52.54”W, 1-IX-2011, L.P. Soares \& M.T. Fujii (SP468815).

Remarks: the specimens examined resemble those described as Gelidiopsis scoparium (Montagne \& Millardet) De Toni by Abbott (1999) from Hawaii, Littler \& Littler (1997, 2000) from the Caribbean, and N'Yeurt \& Pairy (2010) from French Polynesia. Initially proposed as Gelidium scoparium (Montagne \& Millardet 1862) and later transferred to Gelidiopsis scoparia (De Toni 1900), the new combination Ceratodictyon scoparium was stated 
by Norris (1987) when Gelidiopsis was subsumed within Ceratodictyon. Although nine species of Ceratodictyon are actually recognized, some of them have been infrequently described in the literature and are poorly known. Species of Ceratodictyon are easily recognized in the field by their distinctive stiff, tough, wiry habit, forming tufts with entangled branches. Characters, such as branching, thallus diameter, presence of anastomosis and details of tetrasporangia, are used to distinguish the members of this genus. Ceratodictyon scoparium is dichotomously branched, rarely irregular, and the branches are flattened. Even though variable, these attributes appear to be useful to identify the species and separate it from others. Abbott (1999) assigned to C. scoparium plants up to $4 \mathrm{~mm}$ wide, flattened axes at point of bifurcations and called attention to successive dichotomies that give it a palmate appearance. In this regard, our plants are more similar to those described and illustrated by Littler \& Littler (1997, 2000), characterized by the absence of palmate appearance and branches that vary from 0.7 to $1 \mathrm{~mm}$ wide. Axes palmately branched were also pointed out by Littler \& Littler (2003) from material collected in Papua New Guinea, and N'Yeurt \& Pairy (2010) from Tahiti. However, these morphological variations seem to reflect ecological differences related to wave exposure and depth (Abbott 1999).
A species similar to $C$. scoparium is $C$. repens, which was referred to Brazil by Nunes \& Guimarães (2008) and was also the first report in the Western Atlantic. Worldwide records from C. repens are mainly checklists and lack any descriptions, making it difficult to distinguish the species. In studies where C. repens is described, it is primarily characterized by the presence of palmate branches, a series of bifurcations close together or even trichotomies (N'Yeurt 2001, Littler \& Littler 2003, Oliveira et al. 2005, Nunes \& Guimarães 2008). Specimens of $C$. repens analyzed by De Clerck et al. (2005b) from Kwazulu-Natal and Coppejans et al. (2009) from Sri Lanka have 2-5 dichotomies in a single plane, giving the axes a typical pseudopalmate appearance. Coppejans et al. (2002) from the Mozambican coast reported specimens of $C$. repens dichotomously to subpalmately divided in the upper parts. The possible conspecifity of $C$. repens with $C$. scoparium has been discussed by Skelton \& South (2007) and N'Yeurt \& Pairy (2010), but new studies involving the holotypes are needed. Considering the facts that our material is clearly dichotomously branched in the apices, with rare palmate branches, and that $C$. repens could be a synonym of $C$. scoparium, we prefer to consider the plants analyzed here as C. scoparium. Rocha-Jorge

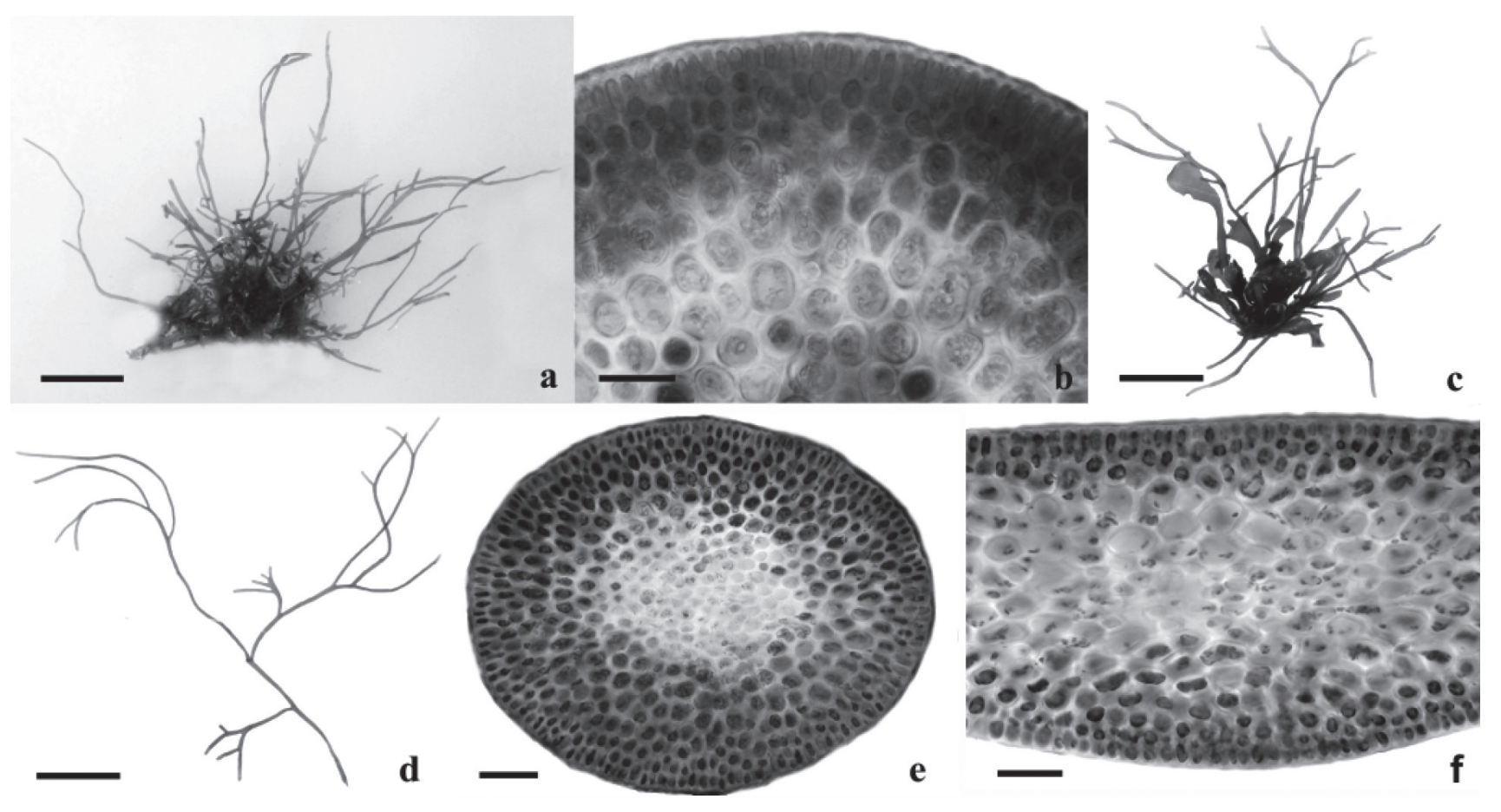

Figure 10. a-b. Ceratodictyon planicaule. a. General habit. b. Transverse section of the median region of thallus. c-f. Ceratodictyon scoparium. c-d. Range of habit variation. e. Transverse section of the basal region of thallus. $\mathrm{f}$. Transverse section of the median region of thallus. Scale bars $=1 \mathrm{~cm}(\mathrm{a}), 25 \mu \mathrm{m}(\mathrm{b}), 1 \mathrm{~cm}(\mathrm{c}, \mathrm{d}), 50 \mu \mathrm{m}(\mathrm{e}, \mathrm{f})$. 
et al. (2012) recorded C. scoparium from Brazilian southeast coast, but description and illustrations are provided here and our data confirm the occurrence of C. scoparium for the South Atlantic coast.

Habitat: collected in association with Solieria filiformis (Kützing) Gabrielson.

\section{Discussion}

The present study has added to taxonomic knowledge about the floristic richness of the Brazilian coastal zone. It should be noted that some new occurrences herein described correspond to small, filamentous and epiphytic seaweeds, especially in the family Ceramiaceae, which are usually overlooked in floristic surveys. This highlights the importance of conducting systematic floristic studies that can detect the presence of this important component of red algae flora. Besides these smaller species, future studies should focus on other poorly studied groups, such as the non-geniculate calcareous seaweeds of the subclass Corallinophycidae, as well as other rarely investigated environments, such as subtidal habitats. The number of new occurrences will probably increase as soon as detailed studies on these other groups and subtidal surveys have been done.

Compiling the data available in the literature plus the results of this study, 190 taxa of red seaweeds are referred to the Ceará State. The figure 11 shows an overview of the distribution of red seaweeds in the Brazilian coast, from data obtained in Menezes et al. (2018). The Brazilian Southeast coast is the region with the best known flora and the Espírito Santo State has the highest number of red seaweeds. This scenario had already been observed by Fujii et al. (2008) when presented an update of the diversity of benthic marine algae from Brazil. In relation to the Northeast region, the Ceará State had the knowledge of its flora improved with the development of the present study. Thus, Bahia, Ceará and Pernambuco are the States with the highest diversity of red seaweeds in the Brazilian Northeast.

Even with these findings of new records, present phycological knowledge on the marine flora of this region remains incomplete, lagging far behind that of other Brazilian States, such as Espírito Santo, Rio de Janeiro, São Paulo and Bahia. This can be explained by the low number of taxonomic research studies carried out in Ceará and scarcity of collections from the subtidal areas, which tend to be more expensive

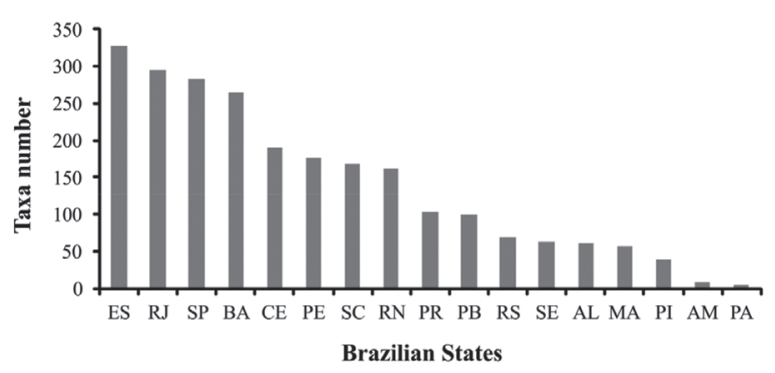

Figure 11. Distribution of red seaweeds taxa by Brazilian States.

and require more logistic arrangements. The regional floristic data obtained in the present study does, however, lead to knowledge that further enriches the biodiversity of this region, provide a baseline for further works, and act as tool for policymakers in the process of developing conservation steps.

\section{Acknowledgements}

LPS thanks the Coordenação de Aperfeiçoamento de Pessoal de Nível Superior (CAPES) for the PhD Fellowship (Proc. N ${ }^{\circ}$ 23038.000077/2010-38) and Conselho Nacional de Desenvolvimento Científico e Tecnológico (CNPq) for the Postdoctoral Fellowship (Proc. N $\left.{ }^{o} 150848 / 2015-3\right)$. MTF thanks CNPq for the Productivity Fellowship (Proc. No 303915/20137). The authors are grateful to Dra. Maria Beatriz de Barros-Barreto for help in Ceramium species identification. Beneficiary of the financial support from CAPES - Brazil.

\section{Literature cited}

Abbott, I.A. 1999. Marine red algae of the Hawaiian Islands. Bishop Museum Press, Honolulu.

Albornoz, O. \& Ganesan E.K. 1994. Marine macroalgae of Falcón State, Venezuela-2: Two new additions of Rhodophyta for Venezuela. Boletín del Centro de Investigaciones Biológicas 28: 19-32.

Athanasiadis, A. 1996. Morphology and classification of the Ceramioideae (Rhodophyta) based on phylogenetic principles. Opera Botanica 128: 1-216.

Azevedo, C.A.A. 2016. Diversity and phylogeny of the order Halymeniales (Rhodophyta) on the Brazilian coast. Doctoral Thesis, Universidade de São Paulo, São Paulo.

Baptista, L.R.M. 1977. Flora ilustrada do Rio Grande do Sul: Flora marinha de Torres (Chlorophyta, Xanthophyta, Phaeophyta, Rhodophyta). Boletim do Instituto de Biociências da Universidade Federal do Rio Grande do Sul 37: 1-248. 
Barreto, M.B.B. \& Yoneshigue-Valentin, Y. 2001. Aspectos morfológicos do gênero Ceramium Roth (Ceramiaceae, Rhodophyta) no estado do Rio de Janeiro. Hoehnea 28: 77-110.

Barros-Barreto, M.B., Fujii, M.T. \& YoneshigueValentin, Y. 2007. Morphological study of Ceramium clarionense (Ceramiaceae, Rhodophyta) in the Atlantic Ocean. Cryptogamie, Algologie 28: 129-139.

Barros-Barreto, M.B., McIvor, L., Maggs, C. \& Ferreira, P.C.G. 2006. Molecular systematics of Ceramium and Centroceras (Ceramiaceae, Rhodophyta) from Brazil. Journal of Phycology 42: 905-921.

Boo, G.H., Nguyen, T.V., Kim, J.Y., Le Gall, L., Rico, J.M., Bottalico, A. \& Boo, S.M. 2016. A revised classification of the Gelidiellaceae (Rhodophyta) with descriptions of three new genera: Huismaniella, Millerella and Perronella. Taxon 65: 965-979.

Braga, M.R.A. 1986. Estudos taxonômicos em Gigartina teedii (Roth) Lamouroux e G. elegans Greville in SaintHilaire (Rhodophyta, Gigartinales). Revista Brasileira de Botânica 9: 191-199.

Cabrera, R., O'Shields, B. \& López-Bautista, J.M. 2009. Confirmación molecular de Chondracanthus saundersii C. W. Schneider et C. E. Lane para Cuba. Revista de Investigaciones Marinas 30: 85-89.

Cardinale, B.J., Duffy, J.E., Gonzalez, A., Hooper, D.U., Perrings, C., Venail, P., Narwani, A., Mace, G.M., Tilman, D., Wardle, D.A., Kinzing, A.P., Daily, G.C., Loreau, M., Grace, J.B., Larigauderie, A., Srivastava, D.S. \& Naeem, S. 2012. Biodiversity loss and its impact on humanity. Nature 486: 59-67.

Carvalho, L.R., Fujii, M.T., Roque, N.F., Kato, M.J. \& Lago, J.H.G. 2003. Aldingenin A, new brominated sesquiterpene from red algae Laurencia aldingensis. Tetrahedron Letters 44: 2637-2640.

Carvalho, L.R., Fujii, M.T., Roque, N.F. \& Lago, J.H.G. 2006. Aldingenin derivatives from the red alga Laurencia aldingensis. Phytochemistry 67: 1331-1335.

Cassano, V. 2009. Taxonomia do complexo Laurencia (Ceramiales, Rhodophyta), no Estado do Rio de Janeiro, baseada em evidências morfológicas e moleculares. Doctoral Thesis, Universidade de São Paulo, São Paulo.

Cassano, V., Oliveira, M.C., Gil-Rodríguez, M.C., Sentíes, A., Díaz-Larrea, J. \& Fujii, M.T. 2012. Morphological and molecular studies on the Brazilian native red seaweed Laurencia oliveirana (Rhodomelaceae, Ceramiales). Revista Brasileira de Farmacognosia 22: 838-849.

Coppejans, E., Leliaert, F. \& Schils, T. 2002. New records of marine benthic algae for the Mozambican coast, collected at Inhaca Island. South African Journal of Botany 68: 342-348.

Coppejans, E., Leliaert, F., Dargent, O., Gunasekara, R. \& De Clerck, O. 2009. Sri Lanka Seaweeds: Methodologies and field guide to the dominant species. Abc Taxa 6: 1-265.
Cordeiro-Marino, M. 1978. Rodofíceas bentônicas marinhas do Estado de Santa Catarina. Rickia 7: 1-243.

Cribb, A.B. 1983. Marine algae of the southern Great Barrier Reef. Part 1. Rhodophyta. Australian Coral Reef Society, Brisbane.

Dawes, C.J. \& Mathieson, A.C. 2008. The seaweeds of Florida. University Press of Florida, Florida.

Dawson, E.Y. 1953. Marine Red Algae of Pacific Mexico. Part 1. Bangiales to Corallinaceae Subf. Corallinoidae. Allan Hancock Pacific Expeditions 17: 1-409.

Dawson, E.Y. 1962. Marine Red Algae of Pacific Mexico. Part 7. Ceramiales: Ceramiaceae, Delesseriaceae. Allan Hancock Pacific Expeditions 26: 1-207.

De Clerck, O. Bolton, J.J., Anderson, R.J., Coppejans, E., Bolton, J. \& Anderson, R.L. 2005b. Guide to the seaweeds of KwaZulu-Natal. National Botanic Garden of Belgium, Meise.

De Clerck, O., Gavio, B., Fredericq, S., Cocquyt, E. \& Coppejans, E. 2005a. Systematic reassessment of the red algal genus Phyllymenia (Halymeniaceae, Rhodophyta). European Journal of Phycology 40: 169-178.

De Toni, G.B. 1900. Sylloge algarum omnium hucusque cognitarum. Vol. IV. Florideae. Sectio II. Sumptibus auctoris, Patavii.

Dixon, P.S. \& Irvine, L.M. 1977. Seaweeds of the British Isles. Volume 1. Rhodophyta. Part 1. Introduction, Nemaliales, Gigartinales. British Museum, London.

Dixon, O.S. \& Price, J.H. 1981. The genus Callithamnion (Rhodophyta, Ceramiaceae) in the British Isles. Bulletin of the British Museum, Botany 9: 99-141.

Ferreira, M.M. \& Pinheiro, F.C. 1966. Primeira contribuição ao inventário das algas marinhas bentônicas do nordeste brasileiro. Arquivos da Estação de Biologia Marinha da Universidade Federal do Ceará 6: 59-66.

Ferreira-Correia, M.M. 1969. Epífitas de Digenea simplex (Wulfen) C. Agardh, no Estado do Ceará (Rhodophyta: Rhodomelaceae). Arquivos de Ciências do Mar 9: 63-69.

Ferreira-Correia, M.M. 1987. Rodofíceas marinhas bentônicas do litoral oriental do Estado do Maranhão. Coleção Ciências Biológicas, Série Botânica 1: 1-256.

Ferreira-Correia, M.M. \& Pinheiro-Vieira, F. 1969. Terceira contribuição ao inventário das algas marinhas bentônicas do Nordeste Brasileiro. Arquivos de Ciências do Mar 9: 21-26.

Ferreira Jr, A.V.F., Araújo, T.C.M. \& Coltrinari, L. 2011. Ambientes de formação, processos de cimentação de arenitos de praia e indicadores de variações do nível do mar. Revista Brasileira de Geografia Física 5: 938-960.

Forest, F., Crandall, K.A., Chase, M.W. \& Faith, D.P. 2015. Phylogeny, extinction and conservation: embracing uncertainties in a time of urgency. Philosophical transactions of the Royal Society B 370: 1-8.

Forzza, R.C., Baumgratz, J.F.A. \& Bicudo, C.E.M. et al. 2012. New Brazilian Floristic List Highlights Conservation Challenges. BioScience 62: 39-45. 
Fujii, M.T., Barata, D., Chiracava, S. \& Guimarães, S.M.P.B. 2008. Cenário brasileiro da diversidade de algas marinhas bentônicas e sua contribuição para a política de conservação dos recursos naturais e do meio ambiente. In: $59^{\circ}$ Congresso Nacional de Botânica. Atualidades, Desafios e Perspectivas da Botânica no Brasil. Imagem Gráfica e Editora Ltda, Natal, pp. 375-377.

Fujii, M.T., Cassano, V., Stein, E.M. \& Carvalho, L.R. 2011. Overview of the taxonomy and of the major secondary metabolites and their biological activities related to human health of the Laurencia complex (Ceramiales, Rhodophyta) from Brazil. Revista Brasileira de Farmacognosia 21: 268-282.

Fujii, M.T. \& Sentíes, G.A. 2005. Taxonomia do complexo Laurencia (Rhodomelaceae, Rhodophyta) do Brasil, com ênfase nas espécies dos estados de São Paulo e do Espírito Santo. Monografías Ficológicas 2: 69-135.

García, M. \& Gómez, S. 2009. Estudio morfológico de Ceramium clarionense Setchell \& N.L. Gardner (Ceramiaceae, Ceramiales, Rhodophyta), uma novedad para el Mar Caribe. Ernstia 19: 97-107.

García, M., Gil, N. \& Gómez, S. 2008. Nuevos registros de Herposiphonia parca y H. arcuata (Rhodomelaceae, Rhodophyta), para la costa de Venezuela. Ernstia 18: 59-70.

Gargiulo, G.M., Morabito, M. \& Manghisi, A. 2013. A reassessment of reproductive anatomy and postfertilization development in the systematics of Grateloupia (Halymeniales, Rhodophyta). Cryptogamie, Algologie 34: 3-35.

Guimarães, S.M.P.B. 1990. Rodofíceas marinhas bentônicas do Estado do Espírito Santo: ordem Cryptonemiales. Doctoral Thesis, Universidade de São Paulo, São Paulo.

Guimarães, S.M.P.B. 2006. A revised checklist of benthic marine Rhodophyta from the State of Espírito Santo, Brazil. Boletim do Instituto de Botânica 17: 143-194.

Guiry, M.D. \& Guiry, G.M. 2017. AlgaeBase. World-wide electronic publication, National Univeristy of Ireland, Galway. Available in http://www.algaebase.org (access in 29-VI-2017).

Gurgel, C.F.D., Fredericq, S. \& Norris, J.N. 2003. Gracilariopsis silvana sp. nov., G. hommersandii sp. nov., and G. cata-luziana sp. nov., three new species of Gracilariaceae (Gracilariales, Rhodophyta) from the Western Atlantic. Hidrobiológica 13: 57-68.

Gurgel, C.F.D., Fredericq, S. \& Norris, J.N. 2004. Molecular systematics and taxonomy of flattened species of Gracilaria Greville (Gracilariaceae, Gracilariales, Rhodophyta) from the Western Atlantic. In: I.A. Abbott \& K.J. McDermid (eds.). Taxonomy of economic seaweeds, with reference to the Pacific and other locations. vol. IX, Hawaii Sea Grant College Program, University of Hawaii, Honolulu, HI, USA, pp. 159-199.
Hay, M.E. \& Norris, J.N. 1984. Seasonal reproduction and abundance of six sympatric species of Gracilaria Grev. (Gracilariaceae; Rhodophyta) on a Caribbean subtidal sand plain. Hydrobiologia 116/117: 63-72.

Hwang, I.-K. \& Kim, H.-S. 2011. Algal flora of Korea. Rhodophyta: Florideophyceae: Nemaliophycidae: Acrochaetiales, Colaconematales, Palmariales, Nemaliales. Nemalian red algae. v. 4, n. 2. National Institute of Biological Resources, Korea.

Hollenberg, G.J. 1968. An account of the species of red alga Herposiphonia occurring in the Central and Western Tropical Pacific Ocean. Pacific Science 22: 536-559.

Horta, P.A., Amâncio, E., Coimbra, C.S. \& Oliveira, E.C. 2001. Considerações sobre a distribuição e origem da flora de macroalgas marinhas brasileiras. Hoehnea 28: 243-265.

Joly, A.B. 1965. Flora marinha do litoral norte do Estado de São Paulo e regiões circunvizinhas. Boletim da Faculdade de Filosofia, Ciências e Letras da Universidade de São Paulo (Botânica 21) 294: 1-393.

Joly, A.B. \& Oliveira Filho, E.C. 1971. The female gametophyte of Dohrniella antillarum var. brasiliensis. Symposium on Investigations and Resources of the Caribbean Sea and Adjacent Regions, pp. 363-365.

Joly, A.B., Cordeiro, M., Mendoza, M.L., Yamaghisui, N. \& Ugadim, Y. 1963. Additions to the marine flora of Brazil. III. Boletim da Faculdade de Filosofia, Ciências e Letras da Universidade de São Paulo, Botânica 20: 7-21.

Knoppers, B., Ekau, W. \& Figueiredo, A.G. 1999. The coast and shelf of east and northeast Brazil and material transport. Geo-Marine Letters 19: 171-178.

Kützing, F.T. 1849. Species algarum. F.A. Brockhaus, Leipzig.

Kylin, H. 1956. Die Gattungen der Rhodophyceen. CWK Gleerups Förlag, Lund.

Le Gall, L., Dalen, J.L. \& Saunders, G.W. 2008. Phylogenetic analyses of the red algal order Rhodymeniales supports recognition of the Hymenocladiaceae fam. nov., Fryeellaceae fam. nov., and Neogastroclonium gen. nov. Journal of Phycology 44: 1556-1571.

Littler, D.S. \& Littler, M.M. 1997. An illustrated marine flora of the Pelican Cays, Belize. Bulletin of the Biological Society of Washington 9: 1-149.

Littler, D.S. \& Littler, M.M. 2000. Caribbean reef plants. An identification guide to the reef plants of the Caribbean, Bahamas, Florida and Gulf of Mexico. Offshore Graphics, Washington.

Littler, D.S. \& Littler, M.M. 2003. South Pacific Reef Plants. A diver's guide to the plant life of the South Pacific Coral Reefs. Offshore Graphics, Washington.

Manoylov, K.M. 2014. Taxonomic identification of algae (morphological and molecular): species concepts, methodologies, and their implications for ecological bioassessment. Journal of Phycology 50: 409-424. 
Mateo-Cid, L.E., Mendoza-González, A.C. \& Searles, R.B. 2003. La tribu Callithamnieae (Ceramiaceae, Rhodophyta) em la costa del Atlántico de México. Hidrobiológica 13: 39-50.

Menezes, M., Moura, C.W.N. \& Bicudo, C.E.M. 2018. Algas In: Flora do Brasil 2020 em construção. Jardim Botânico do Rio de Janeiro. Available in http://floradobrasil.jbbrj.gov.br/reflora/floradobrasil/ FB128463 (access in 27-I-2018).

Miloslavich, P., Klein, E., Díaz, J.M., Hernández, C.E., Bigatti, G., Campos, L., Artigas, F., Castillo, J., Penchaszadeh, P.E., Neill, P.E., Carranza, A., Retana, M.V., Astarloa, J.M.D., Lewis, M., Yorio, P., Piriz, M.L., Rodríguez, D., Yoneshigue-Valentin, Y., Gamboa, L. \& Martín,A. 2011. Marine Biodiversity in the Atlantic and Pacific coasts of South America: Knowledge and Gaps. PLoS ONE doi:10.1371/journal.pone.0014631.

Montagne, J.F.C. \& Millardet, P.M.A. 1862. Botanique, cryptogamie, Algues. In: L. Maillard (ed.). Notes sur l'île de Réunion (Bourbon). Annexe O., Paris.

Moreira, A.R. \& Fujii, M.T. 2010. Notes on the first occurrence of Ceramium fujianum Barros-Barreto \& Maggs (Ceramiaceae, Rhodophyta) from the Caribbean. Caribbean Journal of Science 46: 124-126.

N'Yeurt, A.D.R. 2001. Marine algae from the Suva Lagoon and reef, Fiji. Australian Systematic Botany 14: 243-250.

N'Yeurt, A.D.R. \& Payri, C.E. 2010. Marine algal flora of French Polynesia III. Rhodophya, with additions to the Phaeophyceae and Chlorophyta. Cryptogamie, Algologie 31: 3-205.

Norris, J.N. 2014. Marine algae of the northern Gulf of California II: Rhodophyta. Smithsonian Contributions to Botany 96. Smithsonian Institution Scholarly Press, Washington.

Norris, R.E. 1987. The systematic position of Gelidiopsis and Ceratodictyon (Gigartinales, Rhodophyceae), genera new to South Africa. South African Journal of Botany 53: 239-246.

Nunes, J.M.C. \& Guimarães, S.M.P.B. 2008. Novas referências de rodofíceas marinhas bentônicas para o litoral brasileiro. Biota Neotropica 8: 89-100.

Nunes, J.M.C., Barros-Barreto, M.B. \& Guimarães, S.M.P.B. 2008. A família Ceramiaceae (Ceramiales, Rhodophyta) no estado da Bahia, Brasil. Monografías Ficológicas 3: 75-159.

Oliveira, E.C., Österlund, K. \& Mtoleta, M.S.P. 2005. Marine Plants of Tanzania. A field guide to the seaweeds and seagrasses. Stockholm University, Stockholm.

Oliveira Filho, E.C. 1969. Algas marinhas do sul do Estado do Espírito Santo (Brasil). I-Ceramiales. Boletim da Faculdade de Filosofia e Ciências da Universidade de São Paulo (Botânica 26) 343: 1-277.

Pinheiro-Joventino, F. \& Lima-Verde, N.G. 1988. Ocorrência e distribuição de macroalgas no estuário do Rio Cocó, Fortaleza, Brasil. Arquivos de Ciências do Mar 27: 83-89.
Pinheiro-Joventino, F., Dantas, N.P. \& Maraschin, C.D.H. 1998. Distribuição de algas marinhas no litoral de Fortaleza, Ceará, Brasil. Arquivos de Ciências do Mar 31: 29-40.

Pinheiro-Vieira, F. \& Ferreira, M.M. 1968. Segunda contribuição ao inventário das algas marinhas bentônicas do nordeste brasileiro. Arquivos da Estação de Biologia Marinha da Universidade Federal do Ceará 8: 75-82.

Pinheiro-Vieira, F. \& Ferreira-Correia, M. 1970. Quarta contribuição ao inventário das algas marinhas bentônicas do Nordeste Brasileiro. Arquivos de Ciências do Mar 10: 189-192.

Portugal, A.B., Carvalho, F.L., Carneiro, P.B.M., Rossi, S., Soares, M.O. 2016. Increased anthropogenic pressure decreases species richness in tropical intertidal reefs. Marine Environmental Research 120: 44-54.

Price, I.R. \& Kraft, G.T. 1991. Reproductive development and classification of the red algal genus Ceratodictyon (Rhodymeniales, Rhodophyta). Phycologia 30: 106-116.

Rocha-Jorge, R., Harari, J. \& Fujii, M.T. 2012. Macroalgal composition and its association with local hydrodynamics in the Laje de Santos Marine State Park, Southwestern Atlantic, São Paulo, Brazil. Brazilian Journal of Oceanography 60: 405-419.

Saito, Y. \& Womersley, H.B.S. 1974. The Southern Australian species of Laurencia (Ceramiales: Rhodophyta). Australian Journal of Botany 22: 815-874.

Sansón, M., Reyes, J., Afonso-Carrillo, J. \& Muñoz, E. 2002. Sublittoral and deep-water red and brown algae new from the Canary Islands. Botanica Marina 45: 35-49.

Sansón, M.S. \& Gil-Rodriguez, M.C. 1993. Considerations on the genus Callithamnion (Ceramiaceae, Rhodophyta) in the Canary Islands. Courier Forschungsinstitut Senckenberg 159: 139-142.

Schneider, C.W. 1975. Taxonomic notes on Gracilaria mammillaris (Mont.) Howe and Gracilaria veleroae Dawson (Rhodophyta, Gigartinales). Taxon 24: 643-646.

Schneider, C.W. 1983. The red algal genus Audouinella Bory (Nemaliales: Acrochaetiaceae) from North Carolina. Smithsonian Contributions to the Marine Sciences 22: 1-25.

Schneider, C.W. \& Lane, C.E. 2005. Notes on the marine algae of the Bermudas. 7. Additions to the flora including Chondracanthus saundersii sp. nov. (Rhodophyta, Gigartinaceae) based on $r b c \mathrm{~L}$ sequence analysis. Phycologia 44: 72-83.

Schneider, C.W. \& Searles, R.B. 1991. Seaweeds of southeastern United States: Cape Hatteras to Cape Canaveral. Duke University Press, Durham.

Schneider, C.W. \& Searles, R.B. 1997. Notes on the marine algae of the Bermudas. 1. New records of Antithamnieae and Dohrnielleae (Ceramiaceae, Rhodophyta), including Antithamnionella bermudica sp. nov. Phycologia 36: 12-23. 
Secilla, A. 2012. La familia Ceramiaceae sensu lato en la costa de Bizkaia. Guineana 18: 1-369.

Setchell, W.A. \& Gardner, N.L. 1930. Marine algae of the Revillagigedo Islands Expedition in 1925. Proceedings of the California Academy of Sciences, Ser 4, 19: 109-215.

Shimada, S. \& Masuda, M. 1999. First report of Gelidiella ligulata (Gelidiales, Rhodophyta) in Japan. Phycological Research 47: 97-100.

Silva, I.B. \& Fujii, M.T. 2012. The genus Herposiphonia (Ceramiales, Rhodophyta) in the Coral Reefs Environmental Protection Area, Northeastern Brazil, with new records for Brazil and the Atlantic Ocean. Brazilian Journal of Botany 35: 107-118.

Skelton, P.A. \& South, G.R. 2007. The benthic marine algae of the Samoan Archipelago, South Pacific, with emphasis on the Apia district. Nova Hedwigia Beiheft 132: 1-349.

Soares, L.P. 2015. Diversidade das rodofíceas marinhas bentônicas do estado do Ceará, Brasil, baseada em evidências morfológicas e moleculares. Doctoral Thesis, Instituto de Botânica, São Paulo.

Soares, L.P. \& Fujii, M.T. 2012. Novas ocorrências de macroalgas marinhas bentônicas no estado de Pernambuco, Brasil. Rodriguésia 63: 557-570.

Soares, L.P., Gurgel, C.F.D. \& Fujii, M.T. 2015. Taxonomic reassessment of Gracilaria cearensis (Rhodophyta, Gracilariales), a poorly defined yet common flattened species based on morphological and molecular analysis including topotype collections. Phytotaxa 201: 241-255.

Spalding, M.D., Fox, H.E., Allen, G.R., Davidson, N., Ferdaña, Z.A., Finlayson, M., Halpern, B.S., Jorge, M.A., Lombana, J.A., Lourie, S.A., Martin, K.D., McManus, E., Molnar, J., Recchia, C.A. \& Robertson, J. 2007. Marine ecoregions of the world: a bioregionalization of coastal and shelf areas. BioScience 57: 573-583.

Stegenga, H. \& Vroman, M. 1987. Notes on some Ceramiaceae (Rhodophyta) from Curaçao, especially those from the exposed northeast coast. Blumea 32: 397-426.

Taylor, W.R. 1943. Marine algae from Haiti collected by H.H. Bartlett in 1941. Papers of the Michigan Academy of Sciences, Arts and Letters 28: 143-163.

Taylor, W.R. 1960. Marine algae of the eastern tropical and subtropical coasts of the Americas. The University of Michigan Press, Ann Arbor.

Taylor, W.R. \& Arndt, C.H. 1929. The marine algae of the southwestern Peninsula of Hispaniola. American Journal of Botany 16: 651-662.
Testa, V. \& Bosence, D.W.J. 1998. Carbonate-siliciclastic sedimentation on a high-energy, ocean-facing, tropical ramp, NE Brazil. In: V.P. Wroght \& T.P. Burchette (eds.). Carbonate Ramps, The Geological Society, London, pp. 55-71.

Torres, J., Pereira, S.M.B. \& Yoneshigue-Valentin, Y. 2004. Ceramiaceae (Rhodophyta) de áreas recifais do estado de Pernambuco, Brasil. Hoehnea 31: 119-149.

Ugadim, Y. 1973. Algas marinhas bentônicas do litoral sul do Estado de São Paulo e do litoral do Estado do Paraná. III - Rhodophyta (3). Ceramium (CeramiaceaeCeramiales). Boletim de Zoologia e Biologia Marinha, Nova Série 30: 691-712.

Ugadim, Y. 1974. Algas marinhas bentônicas do litoral sul do Estado de São Paulo e do litoral do Estado do Paraná. III - Divisão Rhodophyta. (1). Goniotricales, Bangiales, Nemalionales e Gelidiales. Boletim de Botânica da Universidade de São Paulo 2: 93-137.

Ugadim, Y. 1976. Ceramiales (Rhodophyta) do litoral sul do Estado de São Paulo e do litoral do Estado do Paraná (Brasil). Boletim de Botânica da Universidade de São Paulo 4: 133-172.

Ugadim, Y., Guimarães, S.M.P. B. \& Kanagawa, A.I. 1986. Estudos em Acrothamnion, Anthithamnion e Anthithamnionella (Rhodophyta, Ceramiales) do Brasil. Rickia 13: 35-47.

Vital, H., Gomes, M.P., Tabosa, W.F., Frazão, E.P., Santos, C.L.A. \& Plácido Jr, J.S. 2010. Characterization of the Brazilian continental shelf adjacent to Rio Grande do Norte state, NE Brazil. Brazilian Journal of Oceanography 58: 43-54.

Vital, H., Stattegger, K., Amaro, V.E., Schwarzer, K., Frazão, E.P., Tabosa, W.F. \& Silveira, I.M. 2008. A modern high-energy siliciclastic-carbonate platform: continental shelf adjacent to northern Rio Grande do Norte state, northeastern Brazil. Journal of Sedimentary Research 90: 175-188.

Woelkerling, W.J. 1973. The Audouinella complex (Rhodophyta) in the Western Sargasso Sea. Rhodora 75: 78-101.

Womersley, H.B.S. 2003. The marine benthic flora of southern Australia-Part IIID Ceramiales, Delesseriaceae, Sarcomeniaceae, Rhodomelacae. Australian Biological Resources Study \& State Herbarium of South Australia, Canberra \& Adelaide.

Wynne, M.J. 2017. A checklist of benthic marine algae of the tropical and subtropical Western Atlantic: fourth revision. Nova Hedwigia 145: 1-202.

Yoneshigue, Y. 1985. Taxonomie et ecologie des algues marines dans la Région de Cabo Frio (Rio de Janeiro, Bresil). Thèse (Docteur d'Etat-Sciences), L' Universite D’Aix-Marseille II, Luminy. 